\title{
Synthesis of Indigo-Dyes from Indole Derivatives by Unspecific Peroxygenases and Their Application for In-Situ Dyeing
}

\author{
René Ullrich ${ }^{1,+} \oplus$, Marzena Poraj-Kobielska ${ }^{1,+} \mathbb{\oplus}$, Owik M. Herold-Majumdar ${ }^{2,+}{ }^{,}$Jesper Vind ${ }^{2}$ \\ and Martin Hofrichter ${ }^{1, *}$ \\ 1 Department of Bio- and Environmental Sciences, TU Dresden-International Institute Zittau, Markt 23, \\ 02763 Zittau, Germany; rene.ullrich@tu-dresden.de (R.U.); marzena.poraj-kobielska@tu-dresden.de (M.P.-K.) \\ 2 Novozymes A/S, Krogshøjvej 36, 2880 Bagsvaerd, Denmark; owik.herold@web.de (O.M.H.-M.); \\ jvi@novozymes.com (J.V.) \\ * Correspondence: martin.hofrichter@tu-dresden.de \\ + These authors contributed equally.
}

check for

updates

Citation: Ullrich, R.; Poraj-Kobielska, M.; Herold-Majumdar, O.M.; Vind, J.; Hofrichter, M. Synthesis of Indigo-Dyes from Indole Derivatives by Unspecific Peroxygenases and Their Application for In-Situ Dyeing. Catalysts 2021, 11, 1495. https:// doi.org/10.3390/catal11121495

Academic Editors: Rodica-Mihaela Dinică and Lidia Favier

Received: 22 November 2021

Accepted: 7 December 2021

Published: 9 December 2021

Publisher's Note: MDPI stays neutral with regard to jurisdictional claims in published maps and institutional affiliations.

Copyright: (c) 2021 by the authors. Licensee MDPI, Basel, Switzerland. This article is an open access article distributed under the terms and conditions of the Creative Commons Attribution (CC BY) license (https:// creativecommons.org/licenses/by/ $4.0 /)$.

\begin{abstract}
Tyrian purple (also known as royal or imperial purple) is the oldest known commercial pigment and still one of the most expensive dyes, often associated with the wardrobes of clergy and royalty. It is a brominated derivative of indigo, a natural dye that has been used since $4000 \mathrm{BC}$. Moreover, just recently, the therapeutic value of indigoids for the treatment of several disorders was discovered. The manufacturing of indigo derivatives by the existing chemical routes has become increasingly uninteresting due to the use of aggressive reagents, expensive starting materials and high-energy costs. Thus, both dyestuff manufacturers and the pharmaceutical industry are interested in the development of gentle preparation methods of indigoids from simple precursors. Here, we describe a simple enzymatic method for the one-step synthesis of Tyrian purple and other indigo derivatives with fungal peroxygenases (UPO, EC 1.11.2.1). The reaction does not require complex co-substrates and works well in phosphate buffers with $\mathrm{H}_{2} \mathrm{O}_{2}(<0.1 \mathrm{wt} \%)$ and less than $5 \%(v / v)$ acetonitrile as co-solvent. We demonstrate the scaling up of the reaction to 10 Liters and established thereupon an environmentally friendly combined synthesis and in-situ dyeing process, further simplifying the manufacturing of vat-dyed fabrics. Eventually, we screened a number of halogen-substituted indoles in the search for novel indigo derivatives, which may be of interest for pharmaceutical and/or dyeing purposes.
\end{abstract}

Keywords: peroxygenase; peroxidase; Tyrian purple; dye; indigo; enzymatic dyeing; in situ dyeing

\section{Introduction}

Tyrian purple, also known as royal, imperial or Phoenician purple, was the most expensive dye in the ancient world. It is without doubt the oldest known commercial pigment and the subject, together with indigo, of the 'first' chemical industry [1]. From ancient times, the dye has been produced from secretions of various species of snails found off the Atlantic and Mediterranean coasts. Paul Friedländer, who identified the structure of the Tyrian purple as 6,6'-dibromoindigo in 1909, required 12,000 Murex brandaris (L.) snails (currently termed as Bolinus brandaris (L.)) to isolate $1.4 \mathrm{~g}$ of the pure pigment [2-4]. In contrast, indigo was obtained in a simpler way by extraction from plants (e.g., Indigofera tinctoria (L.), Isatis tinctoria (L.)), where it occurs as a glycosylated precursor (indican) that can be converted to indigo by hydrolysis and oxidation [5]. On that basis, indigo was already commercialized in medieval times and started its triumph as denim dye in the world.

Today indigo is the largest dyestuff used worldwide with an annual production of $50,000 \mathrm{t}$ [6]. This amount cannot be supplied from plant sources and therefore chemical syntheses had already been established by the end of the 19th century. The first routes to indigo were described by Baeyer and Emmerling in 1870 via reduction of isatin and in 1878 by Baeyer and Drewsen via aldol condensation [5,7]. The first patent was successfully filed 
in 1890 [8] and consequently, the production of indigo from natural sources was replaced by synthetic indigo in the following years. Nowadays, the chemical synthesis is based on an improved method described by Pfleger in 1901 as a variation of the Heumann synthesis [9]. The reaction pathway starts with the formation of $\mathrm{N}$-phenylglycine by the reaction of aniline, formaldehyde and hydrogen cyanide. After hydrolyzation of the primary product $\mathrm{N}$-phenylglycinenitrile to $\mathrm{N}$-phenylglycine, conversion to indoxyl occurs at $220{ }^{\circ} \mathrm{C}$ in a mixture of sodium amide, sodium hydroxide and potassium hydroxide [10]. In the end, indigo will be formed by dimerization of indoxyl under aerobic conditions $[3,4,11-17]$. Today, nearly all indigo traded is synthetic and based on the Heumann-Pfleger synthesis described above [9].

The synthesized vat dye is shipped to the dye house in powder form or as a reduced leuco-indigo solution, where cotton yarns are then dyed in a multistep process involving several leuco-indigo baths intermitted by air exposition stages to oxidize the leuco-indigo to indigo and achieve a ring-dyeing of the cotton yarn. The success of vat dyes is based on their excellent color fastness and the everlasting fashionable shade of indigo blue.

The vat-dye synthesis and dyeing process is energy demanding, results in high amounts of hazardous waste products and requires elaborate purification procedures [18,19]. Together with the recent awareness of aniline contamination in denim garments, originating from the indigo synthesis, a desire to find alternative synthesis routes has risen.

Ensley et al. described in 1983 a microbial route to indigo using whole-cell biocatalysis starting with tryptophan or indole. Thereby, a recombinant Escherichia coli strain expressing naphthalene dioxygenase was utilized. This enzyme is able to convert indole into cis-indole-2,3-dihydrodiol that spontaneously forms indoxyl under elimination of water [20]. Mouri et al. tested several other recombinant strains in order to improve this method [21], which is still expensive and has inherent drawbacks in extracting pure indigo from the culture broth. In-vitro systems with biocatalysts were also tested, such as naphthalene 1,2-dioxygenase, cytochrome P450 monooxygenases [5,12,22], including a novel method for indigo synthesis that applies metalloporphyrin-based catalytic systems mimicking P450 catalysis. A comprehensive overview of microbial enzymes forming indigo has recently been published by Fabara and Fraaije [23].

More than 15 years ago, a remarkable extracellular monooxygenase from the agaric fungus Agrocybe aegerita was discovered, which uses $\mathrm{H}_{2} \mathrm{O}_{2}$ as electron acceptor and oxygen donor [24] and hydroxylates aromatic rings and benzylic carbons in naphthalene and aryl alcohols, respectively [25]. In the following years, similar enzymes were found in other fungi, such as Marasmius rotula [26], Marasmius wettsteinii [27], Coprinellus radians [28] and Chaetomium globosum [29]. These enzymes catalyze a range of oxyfunctionalization reactions and were therefore named unspecific peroxygenases (UPOs). Since 2011, the enzyme type has been listed in the enzyme nomenclature system under EC 1.11.2.1. Reactions catalyzed by UPOs comprise, in addition to hydroxylation, epoxidation of isolated double bonds and aromatic systems [30], $\mathrm{N}$-oxidation and sulfoxidation [31,32], $\mathrm{O}$ - and $\mathrm{N}$-dealkylation [33,34], deacylation $[27,35]$ and other reactions, including the conversion of complex pharmaceuticals [36-40]. All UPOs characterized so far are extracellular, rather stable heme-thiolate proteins that are independent of expensive redox cofactors or auxiliary flavoproteins but need merely stoichiometric concentrations of peroxide (e.g., $\mathrm{H}_{2} \mathrm{O}_{2}$ ) for function.

Here we describe a simple enzymatic method for the synthesis of Tyrian purple and other indigoid dyes with different wild-type and recombinantly expressed UPOs, starting from indole or substituted indoles. Indole is a readily available chemical and used today in the flavor and frequencies industry as starting material for the synthesis of diverse heterocyclic products. The reaction requires neither sterile conditions nor any complex co-substrate and works well in phosphate buffer with hydrogen peroxide $\left(\mathrm{H}_{2} \mathrm{O}_{2}<0.1 \%\right)$ as co-substrate and less than $5 \mathrm{vol} \%$ acetonitrile $(\mathrm{ACN})$ as co-solvent. This approach was successfully scaled up to reactor scale $\left(10 \mathrm{dm}^{3}\right)$. Moreover, we developed a novel in-situ dyeing method by combining the synthesis of the indigoid dye with garment dying in one step effectively cutting the complex multistep process to a single step, avoiding elevated 
temperatures, sodium hydroxide and sodium dithionite. A library of 83 UPO mutants following a rational design of the lead candidate enzyme were screened to further improve indigo synthesis and five promising candidates were further tested. Furthermore, we have screened a representative number of chlorine, bromine and fluorine-substituted indoles as well as 5-bromoindoline in the search for novel indigo derivatives, which may be of interest for dyeing and/or pharmaceutical applications.

\section{Results}

2.1. Screening of UPOs for the Conversion of Indole in the Presence of $\mathrm{H}_{2} \mathrm{O}_{2}$

The tested UPOs, rHinUPO, wild-type AaeUPO, rAaeUPO and rCciUPO, readily converted indole (Figure 1). Reactions catalyzed by rHinUPO gave indigo-blue solutions (Figure 1A), while the other UPOs produced an umber-greenish color, probably caused by a mixture of indigo and by-products (Figure 1).

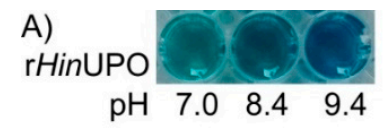

B)

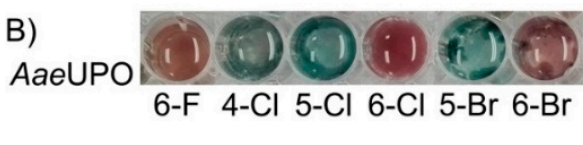

C)
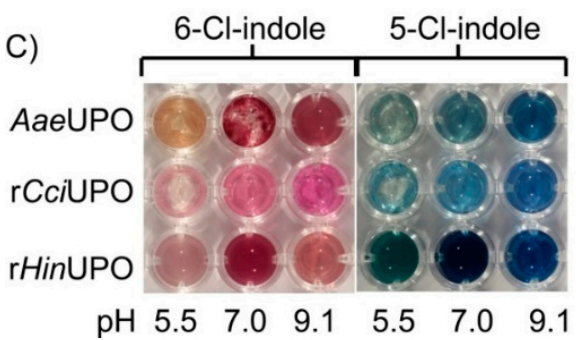

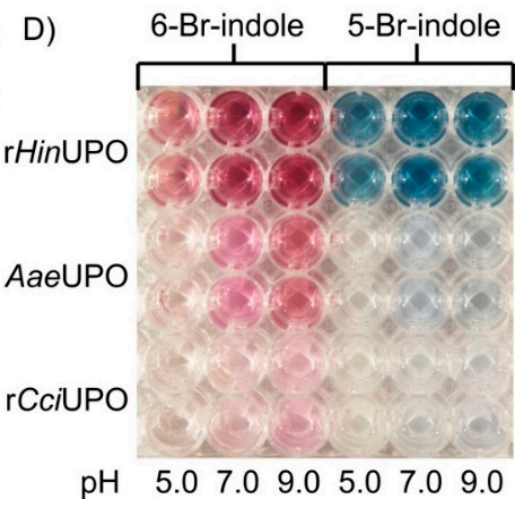

Figure 1. Colored reaction solutions of different UPOs containing indole or halogenated indole derivatives after incubation at $23{ }^{\circ} \mathrm{C}$ for at least $15 \mathrm{~min}$. (A) rHinUPO $1 \mathrm{U} \mathrm{mL}^{-1}, 1.5 \mathrm{mM}$ indole; $3 \mathrm{mM} \mathrm{H}_{2} \mathrm{O}_{2}, 50 \mathrm{mM}$ potassium phosphate buffer (PPB) with different $\mathrm{pH}$ values; (B) AaeUPO $1 \mathrm{U} \mathrm{mL}^{-1}, 2 \mathrm{mM}$ halogenated indole derivative; $5 \mathrm{mM} \mathrm{H}_{2} \mathrm{O}_{2}, 50 \mathrm{mM}$ PPB pH 7.0; (C) different UPOs $1 \mathrm{U} \mathrm{mL}^{-1}, 2 \mathrm{mM}$ 5-Cl- or 6-Cl-indole; $5 \mathrm{mM} \mathrm{H}_{2} \mathrm{O}_{2}, 50 \mathrm{mM}$ PPB with different $\mathrm{pH}$; (D) different UPOs $1 \mathrm{U} \mathrm{mL}^{-1}, 0.4 \mathrm{mM}$ 5-Br- or 6-Br-indole; $0.4 \mathrm{mM} \mathrm{H}_{2} \mathrm{O}_{2}, 20 \mathrm{mM}$ PPB with different $\mathrm{pH}$.

\subsection{Product Identification and Verification of Indoxyl Formation}

On the basis of previous studies [41], we postulated that indole (I) is oxygenated by UPOs via formation of the corresponding 2,3-epoxide. This epoxide tends to isomerize spontaneously to 2-oxindole (II) and 3-oxindole (indoxyl; III) both involving rearomatization as a driving force. Whereas II is stable in aqueous solution, III is a highly reactive and unstable product and rapidly dimerizes under the formation of indigo (IV). To prove this assumption, we incubated relatively stable indoxyl acetate (IA) with a fungal esterase (Mucor miehei) for the ad hoc synthesis of indoxyl (III) and used it as reference for products formed during the conversion of indole (I) by UPOs. The detection of unstable III by mass and UV-spectra was successful, but only under micro-aerobic conditions, i.e., when stripping dissolved dioxygen with helium (Figure S1A). Under such conditions, the color of the reaction solution changed over time $(120 \mathrm{~min})$ from colorless, over yellow and green to blue. Detectable products were indoxyl (III), a related further product (III*, probably a dimeric van-der-Waals adduct) and small amounts of indigo (IV). The latter (IV) was formed after aeration; however, because of its extremely low solubility, just a small 'smear' peak was detectable, which did not accurately reflect the actual amount of indigo formed (compare chromatogram in Figure S1A). Two other products were detectable (XI and XII) from their UV-Vis and mass spectra, which were similar to those of indoxyl (Figure S2). In the presence of 2-oxindole (II) and in the absence of UPOs, conversion of III 
was not observed under otherwise identical conditions, indicating that II does not react with III (Figure S1B); compare also enzymatic oxindole oxidation below). Corresponding micro-aerobic experiments with AaeUPO instead of esterase and using indole (I) and $\mathrm{H}_{2} \mathrm{O}_{2}$ as substrates resulted in the formation of indoxyl (III) as well (Figure 2); however, the main product formed was II (Figure S1C). Small peaks (XIV, XV and in between) of further oxidation products were detectable in the respective chromatogram, probably representing hydroxylated indoles and/or 2-oxindoles (Figure S1C). In fact, AaeUPO was capable of converting 2-oxindole (II) when used as substrate under formation of a hydroxy-2-oxindole (XIV; presumably with the hydroxyl group in position 5 or 6 ) and coupling products causing a brownish color in the reaction vials under aerobic and micro-aerobic conditions (Figure S3). These reactions are seemingly independent of dioxygen.

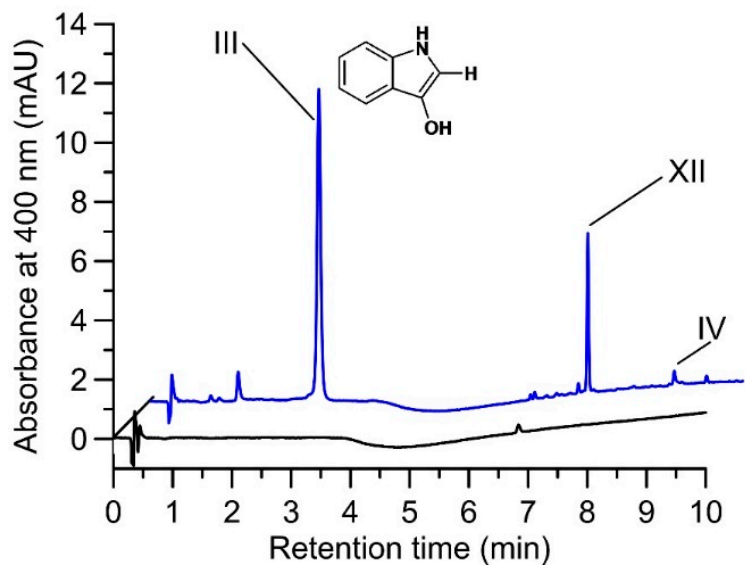

Figure 2. HPLC elution profiles $\left(400 \mathrm{~nm}\right.$ ) of a reaction solution containing $0.04 \mathrm{U} \mathrm{mL}^{-1}$ Aae UPO and $500 \mu \mathrm{M}$ indole in 5\% ACN/50 mM PPB ( $\mathrm{pH} 7$ ) under micro-aerobic conditions (reaction time $20 \mathrm{~min}$ at $23{ }^{\circ} \mathrm{C}$ ). Control without $\mathrm{H}_{2} \mathrm{O}_{2}$ (black line) and after addition of $500 \mu \mathrm{M} \mathrm{H}_{2} \mathrm{O}_{2}$ resulting in the formation of indoxyl (III) and traces of indigo (IV) as well as of an unknown product (XII) (blue line $20 \mathrm{~min}$ ). Note that indole (substrate) does not absorb at $400 \mathrm{~nm}$ and therefore, appears to be absent in the control; the same applies to the enzymatic byproduct 2-oxindole in the reaction solution.

\subsection{The $\mathrm{pH}$ Profile of $r$ HinUPO for the Conversion of Indole}

Indole was readily converted by $\mathrm{rHinUPO}$ in $100 \mathrm{mM}$ Britton-Robinson buffer over a broad $\mathrm{pH}$ range from 2.0 to 11.0, with an optimum around $\mathrm{pH} 7.5$ (Figure S4). The curve shows an untypical bend in the region between $\mathrm{pH} 4.0$ and $\mathrm{pH} 8.0$, first with stagnating ( $\mathrm{pH} 4.0-6.0)$ and then ramping $(\mathrm{pH} 6.0-8.0)$ production of indigo with increasing $\mathrm{pH}$. This $\mathrm{pH}$ dependency of the reaction is not solely explainable by an activity optimum of the enzyme but might also reflect additional factors influencing catalysis.

\subsection{Screening of Rational Design Variants of rHinUPO}

As $\mathrm{rHinUPO}$ showed promising results for the reaction of indole to indigo, a library containing 83 enzyme mutants following rational design was created for further improving the product yield of the reaction.

A first plate screening (data not shown) of the mutants revealed varying amounts of formed indigo and five variants, 0002, 0006, 0032, 0043 and 0044 (compare Table 1), were selected for validation and reaction scaling to $10 \mathrm{~mL}$. 
Table 1. Designed variants of the recombinant peroxygenase of Humicola insolens (rHinUPO).

\begin{tabular}{|c|c|c|}
\hline Variant & Amino Acid & Proposed Effect \\
\hline per27.0002 & A55L & \multirow{5}{*}{$\begin{array}{c}\text { flanks active site on one -helix } \\
\text { removes a potential } N \text {-glycosylation, } \\
\text { which could affect access to the active site } \\
\text { flanks active site on another -helix } \\
\text { presumably affects the long-range } \\
\text { electron transfer (LRET) } \\
\text { presumably affects the LRET }\end{array}$} \\
\hline per27.0006 & N71Q & \\
\hline per27.0032 & I154V & \\
\hline per27.0043 & W183I & \\
\hline per27.0044 & W183V & \\
\hline
\end{tabular}

The results indicate that under aerobic conditions, only variant $0002(66 \%)$ clearly outperformed the recombinant wild-type (rHinUPO, 24\%) in terms of indigo production. The remaining variants were either slightly better or slightly worse in converting indole to indigo compared to the wild-type enzyme. Under micro-aerobic conditions achieved by dioxygen stripping with dinitrogen $\left(\mathrm{N}_{2}\right)$, the wild-type enzyme outperformed all tested variants in terms of indigo yield. Additional air during the reaction had a negative impact on the formation of indigo for all tested enzymes. Total turnover numbers (TTN) of around 1600 could be reached under the best available conditions.

\subsection{In-Situ Dyeing Process and Its Scale up}

The favorable conditions of the novel enzymatic indigoid synthesis described above in the 'material and methods' section ('Common chemical dyeing' and 'Scaled up in-situ dyeing') enabled us to redesign the dyeing process and combine both processes in one step, thus saving raw materials, energy, space and time. To test this novel design, the synthesis was scaled over several steps starting from $0.5 \mathrm{~L}$ over $4 \mathrm{~L}$ to finally $10 \mathrm{~L}$, and a steel-barrel setup (Figure 3) was developed for the combined synthesis and in-situ dyeing. Figure 3 illustrates this experimental setup of the optimized in-situ dyeing process. It was performed in a 25-L stainless steel barrel. The final concentration of the co-solvent ACN could be reduced to $2.5 \%$. The shaker was used to accomplish a largely uniform distribution of the dye, and its speed (150 to $180 \mathrm{rpm}$ ) had a substantial impact on the dyeing result. For this experiment, a piece of white cotton textile $(60 \times 60 \mathrm{~cm} \sim 100 \mathrm{~g})$ was used and $\mathrm{H}_{2} \mathrm{O}_{2}$ added in four portions to protect the enzyme from inactivation. After two hours, the cotton fabric was removed, washed under running water and finally air-dried.

$\mathrm{rHinUPO}$ performed best at laboratory scale using short reaction times. On the other hand, brownish coupling products were formed in preliminary tests with $\mathrm{rHinUPO}$ and rCciUPO over longer times when 6-bromoindole was used as substrate in a larger volume $(0.5 \mathrm{~L}$; data not shown). In contrast, the reaction mixture containing rCciUPO stayed clear and, after $15 \mathrm{~min}$, the envisaged indigoid product precipitated in the form of flakes. Therefore, we decided to continue the upscaling and in-situ dyeing experiments with rCciUPO and 6-bromoindole as enzyme and substrate, respectively.

First, we applied $30 \mathrm{mg}$ of 6-bromoindole $(1.5 \mathrm{mM}), 1.2 \mathrm{mg} \mathrm{L}^{-1} \mathrm{rCciUPO}$ and $5 \mathrm{mM}$ $\mathrm{H}_{2} \mathrm{O}_{2}$ in the 0.5-L setup supplemented with $4 \mathrm{~g}$ of the white cotton fabric. After stirring for one hour, the fabric was removed, while the reaction mixture still contained nonbound dye. Therefore, the ratio of substrate and cotton fabric was halved in all further dyeing experiments. After successfully extending the scale-up to $4 \mathrm{~L}$ (data not shown), we continued with the meanwhile optimized dyeing process in a 10-L steel barrel and achieved satisfactory dyeing results (see Figure 3, step 4). The color of the original white fabric turned to purple (ranging between red and blue) and this color was visually almost identical to that of the chemically synthesized Tyrian purple. 


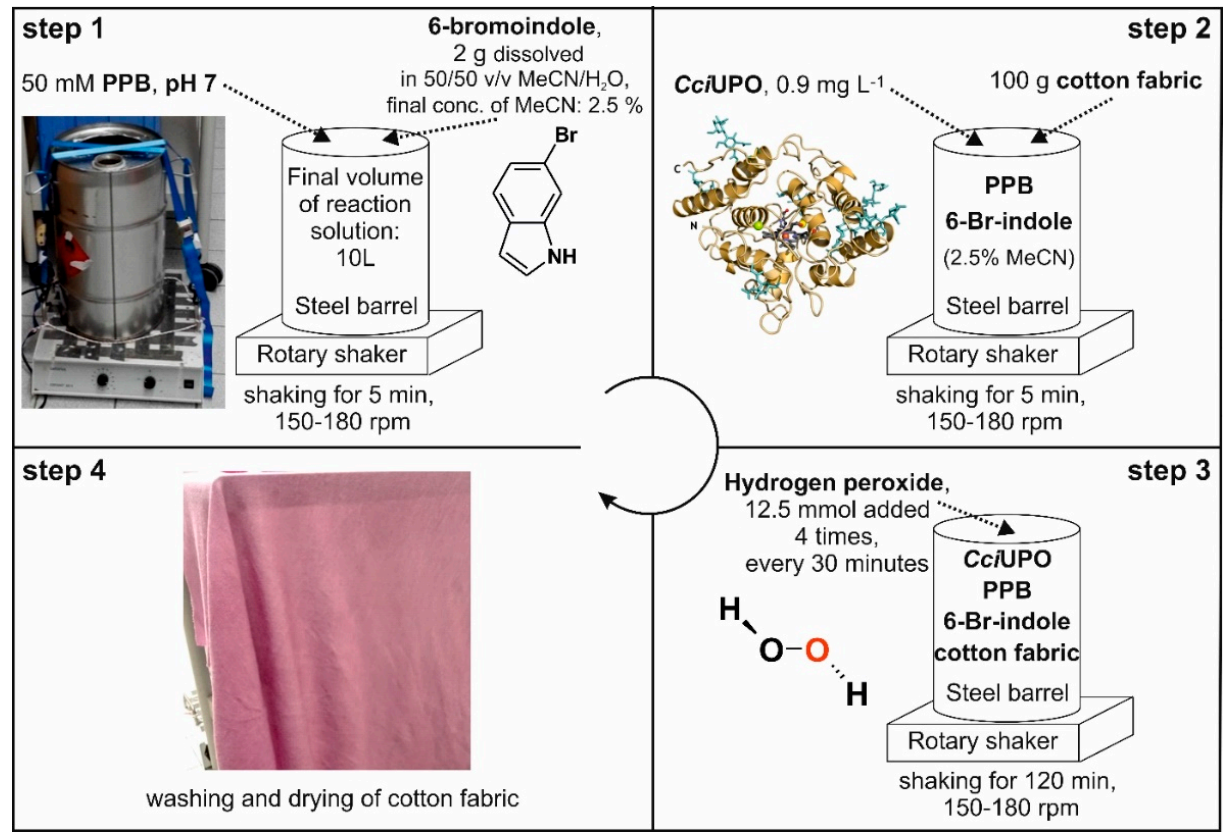

Figure 3. Scheme illustrating the experimental setup of the in-situ dyeing process.

\subsection{Synthesis of Further Halogenated Indigoids Using UPOs}

The bioconversion of further halogenated derivatives of indole yielded even brighter colors compared to Tyrian purple ranging from reddish (when starting from 6-chloroindole) to turquoise (for 5-chloroindole; Figure 1B). The resulting indigoids (dimeric products) were all poorly soluble in water and precipitated. The precipitates were washed with $50 \%$ ACN, dissolved in DMF/MeOH (1:1) and in the case of the AaeUPO products spectroscopically analyzed. The respective UV-Vis spectra showed characteristic bands and for the 6-bromoindole coupling product, the spectrum was almost identical to that of the Tyrian purple standard (Figure 4, spectra on the right). It should be considered that the observed colorfulness (color intensity), most likely, depends both on the catalytic turnover of indoles and the number of by-products formed.

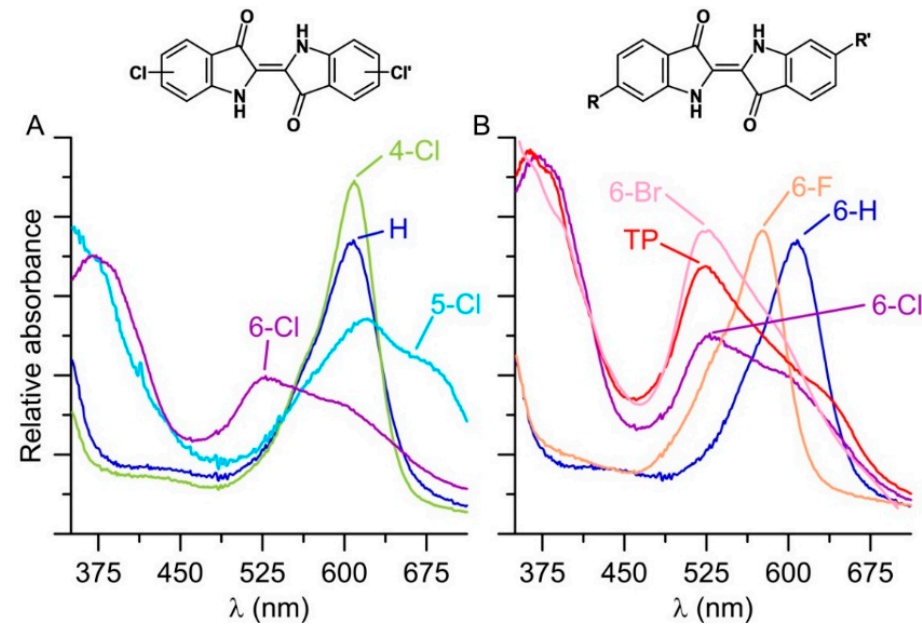

Figure 4. UV-Vis spectra of products precipitating in reaction solutions with Aae $\mathrm{UPO}\left(1 \mathrm{U} \mathrm{mL}^{-1}\right), 2 \mathrm{mM}$ indole derivative; $5 \mathrm{mM} \mathrm{H}_{2} \mathrm{O}_{2}$, and $50 \mathrm{mM} \mathrm{PPB}$ (pH 7.0) at $23^{\circ} \mathrm{C}$. Products were washed with $50 \% \mathrm{ACN}$ and dissolved in DMF/MeOH (1:1). (A) Indigo (blue; analytical standard) and enzymatically formed products derived from 4-chloroindole (green), 5-chloroindole (light blue), 6-chloroindole (purple); (B) Indigo (blue; analytical standard), 6,6'-dibromindigo-Tyrian purple (red, chemical standard) and enzymatic products derived from 6-chloroindole (purple), 6-flouroindole (orange) and 6-bromoindole (pink). 
Furthermore, the biocatalytic conversion of halogenated indoles was influenced by the $\mathrm{pH}$ of the reaction mixture. The best results for all tested UPOs were obtained at neutral and weak alkaline $\mathrm{pH}$ ( $\mathrm{pH}$ 7.0-9.4; compare Figure 1A,C,D). The amount of added substrate also affected the results, as shown in Figure 1. The conversion of 5- and 6-bromoindole by AaeUPO resulted in a brighter color when investing $2 \mathrm{mM}$ of the indigo precursor (Figure 1B) compared to $0.4 \mathrm{mM}$ (AaeUPO, pH 7.0, Figure 1D). The maximum concentration tested was $50 \mathrm{mM}$ (indole) and gave the best regarding color intensity (data not shown).

\subsection{Comparison of UPO-Catalyzed Conversion of 5-Bromoindole and 5-Bromoindoline}

A possible alternative reaction sequence to form reactive indoxyls could start with the hydroxylation of an indoline followed by a second hydroxylation of the formed alcohol at the same carbon (C3) resulting in the corresponding carbonyl hydrate (gem-diol) that is in equilibrium with the indoxyl (keto form) and in turn with the tautomeric enol form. Unfortunately, 6-bromoindoline was not available as a fine chemical, so we compared the conversion of 5-bromoindole and 5-bromoindoline to verify the above assumption. Figure S5 shows a photograph of the corresponding reaction solutions of three different UPOs at different $\mathrm{pH}$ after transfer to a micro-titer plate. The respective Vis-spectra are given in Figure S6. Both figures make clear that most 5,5'-dibromoindigo was formed by rHinUPO with 5-bromoindoline and 5-bromoindole as substrates. In contrast, AaeUPO and $\mathrm{rCciUPO}$ produced just low amounts of 5,5'-dibromoindigo from 5-bromoindole and almost no indigo product from 5-bromoindole. In line with the results obtained for the other tested indole derivatives, neutral and slightly alkaline $\mathrm{pH}$ values were favorable for dye formation. In all cases, formation of the more stable by-product 5-bromo-2-oxindole was observed. Concentration of the latter and of the substrate were quantified by HPLC. The respective results are summarized as bar charts in Figure 5.
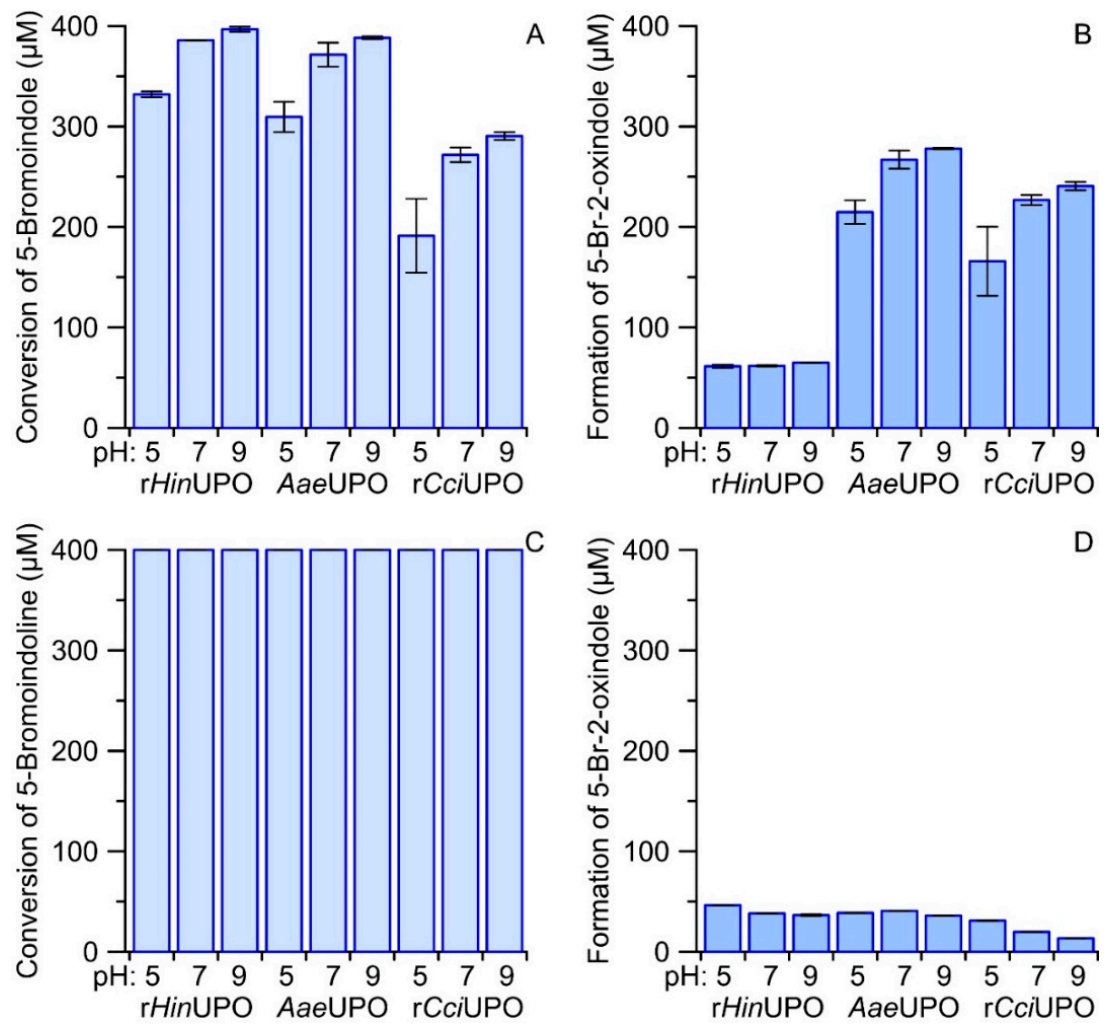

Figure 5. Bar charts comparing the conversion of $400 \mu \mathrm{M}$ 5-bromoindole (A) and 5-bromoindoline (C) by rHinUPO, AaeUPO and rCciUPO $\left(35 \mathrm{mg} \mathrm{L}^{-1}\right)$ at different $\mathrm{pH}(5.0,7.0$ and 9.0) and the formation 5-bromo-2-oxindole (B,D). Reactions were started by adding $\mathrm{H}_{2} \mathrm{O}_{2}(800$ and $400 \mu \mathrm{M}$ for indoline and indole, respectively) and allowed to run for at least two hours at $23^{\circ} \mathrm{C}$. 
Formation of Tyrian purple in dependence of enzyme concentration and the reaction time course.

To investigate the influence of the enzyme dose on product formation, we performed experiments with different enzyme concentrations at constant 6-bromoindole concentration $(400 \mu \mathrm{M})$. Online dye formation was spectrophotometrically monitored and eventually, the reaction mixtures were analyzed by HPLC.

The results of the spectrophotometric analysis are displayed in Figure 6. rHinUPO accomplished higher product formation (at $530 \mathrm{~nm}$ ) compared to $\mathrm{rCciUPO}$ at all tested enzyme dosages. Reduced amounts of UPOs ( $\mathrm{rHinUPO}<12 \mathrm{mg} \mathrm{L}^{-1}, \mathrm{rCciUPO}<110 \mathrm{mg} \mathrm{L}^{-1}$ ) resulted in a delay of product formation of about one minute. With increasing enzyme concentrations, this lag-phase disappeared. Concentrations of $\mathrm{rHinUPO}>12 \mathrm{mg} \mathrm{L}^{-1}$ yielded the maximum amount of product at 1.1 AU, implying that the entire substrate had been converted/oxygenated and that subsequent dimerization had set in. Lower enzyme concentrations were insufficient to oxidize the total amount of added substrate. Figure 6C,D show the change of the respective Vis-spectra over time when using $25 \mathrm{mg} \mathrm{L}^{-1}$ of $\mathrm{rHinUPO}(\mathrm{C})$ or $\mathrm{rCciUPO}(\mathrm{D})$. The $\mathrm{rCciUPO}-$ catalyzed reaction resulted in less product formation compared to $\mathrm{rHinUPO}$. On the other hand, the purity of the formed 6,6'-dibromoindigo was higher in the case of $\mathrm{rCciUPO}$. Figure $6 \mathrm{C}$ illustrates the formation of further products with strong absorbances between 500 and $600 \mathrm{~nm}$. These compounds might comprise hydroxylated derivatives of 6-bromoindole and 6,6'-dibromoindigo. Note that the expectable by-product 6-bromo-2-oxindole did not absorb in the visible range of the spectrum (compare Figure S2II).
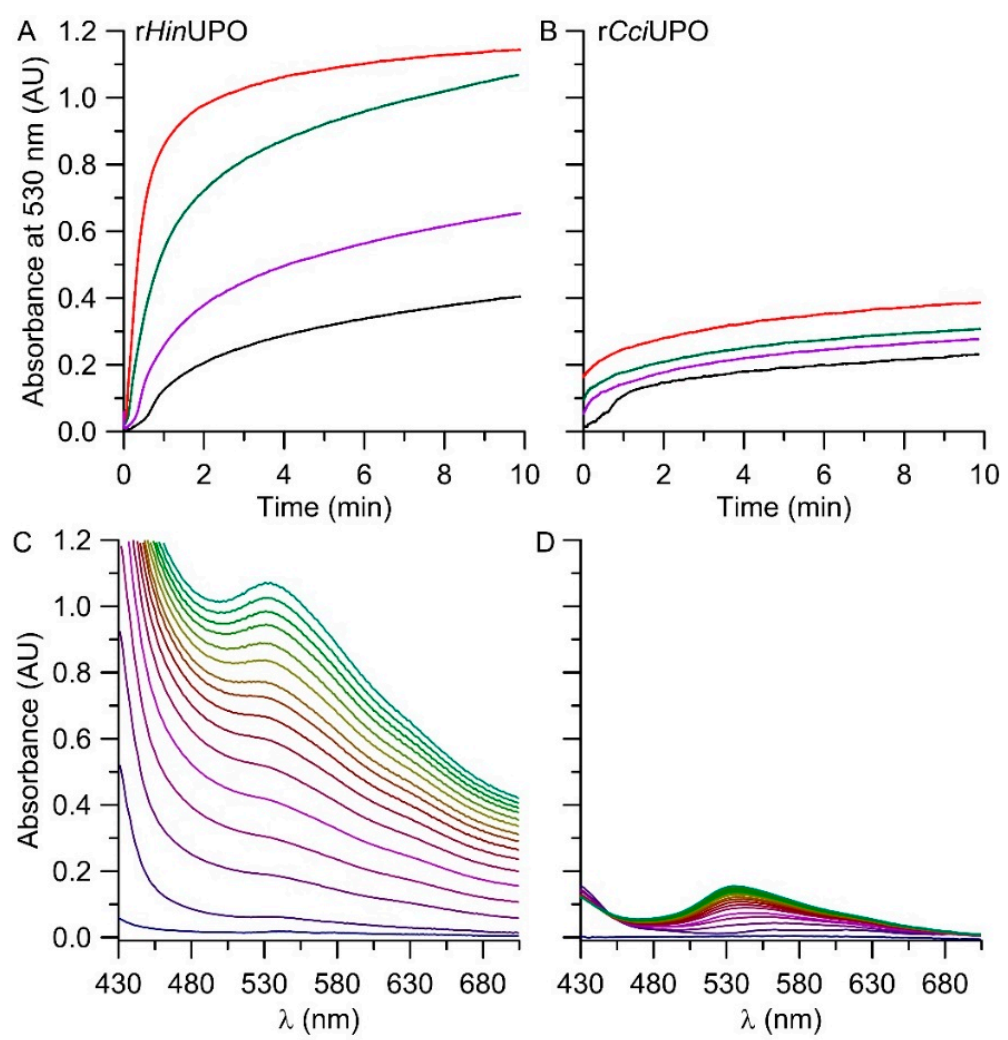

Figure 6. (A,B (above))-time courses of the conversion of 6-bromoindole by rHinUPO (A) at different enzyme concentrations: $3 \mathrm{mg} \mathrm{L}^{-1}$ (black line), $6 \mathrm{mg} \mathrm{L}^{-1}$ (purple line), $12 \mathrm{mg} \mathrm{L}^{-1}$ (green line), $25 \mathrm{mg} \mathrm{L}^{-1}$ (red line) and by rCciUPO (C) with $25 \mathrm{mg} \mathrm{L}^{-1}$ (black line), $110 \mathrm{mg} \mathrm{L}^{-1}$ (purple line), $220 \mathrm{mg} \mathrm{L}^{-1}$ (green line) or $440 \mathrm{mg} \mathrm{L}^{-1}$ enzyme (red line); the reactions were followed by the increase in absorbance at $530 \mathrm{~nm}$ indicating the formation of a colored product (6,6'-dibromoindigo). (C,D (below)) - UV-Vis absorption spectra following product formation in the time scan mode over $15 \mathrm{~min}\left(23^{\circ} \mathrm{C}, \mathrm{pH} 7.0\right)$; (C) with $\mathrm{rHinUPO}\left(25 \mathrm{mg} \mathrm{L}^{-1}\right)$ or (D) with $\mathrm{rCciUPO}\left(25 \mathrm{mg} \mathrm{L}^{-1}\right)$. 
HPLC analyses of the conversion of 6-bromoindole (1) by rHinUPO are summarized in Figure 7. 6-Bromo-2-oxindole (2) was the first reaction product detected in relevant amount. Increasing the concentration of UPO resulted in an increase in the formation of another product with a second hydroxylated carbon $\left(3^{*}\right)$, but the amount of this product did not increase indefinitely when the amount of enzyme was further increased. Rather, further increase in enzyme concentration led to enhanced coupling reactions (oxidative polymerization), while the concentrations of 6-bromo-2-oxindole and $3^{*}$ decreased.

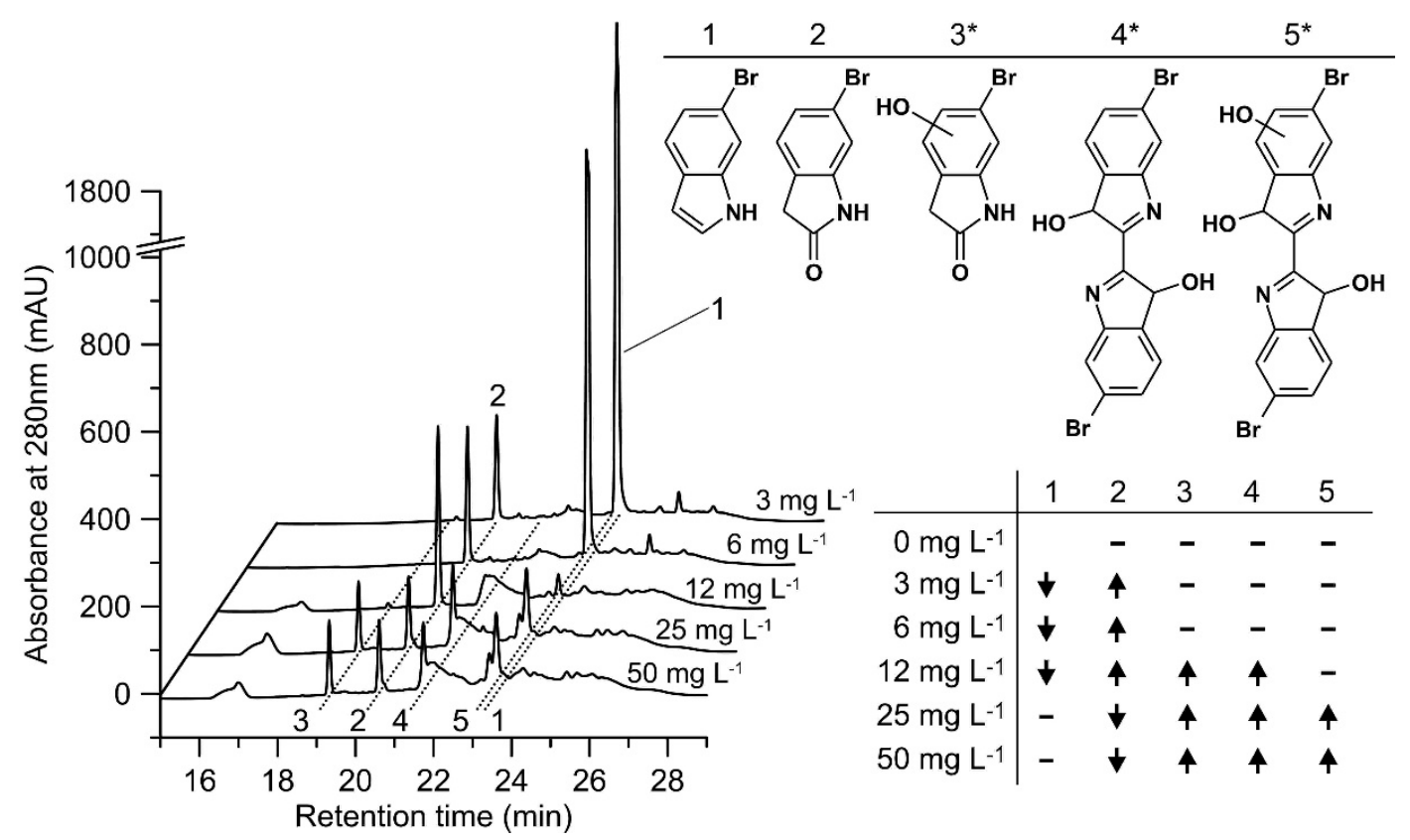

Figure 7. Conversion of 6-bromoindole. Left-HPLC elution profiles of reaction solutions containing different $\mathrm{rHin} \mathrm{UPO}$ concentrations ( $3 \mathrm{mg} \mathrm{L}^{-1}$ to $50 \mathrm{mg} \mathrm{L}^{-1}$ ), $500 \mu \mathrm{M}$ 6-bromoindole and $2000 \mu \mathrm{M} \mathrm{H}_{2} \mathrm{O}_{2}$ in $\mathrm{PPB}$ ( $\mathrm{pH}$ 7.0); right above-structures of detected products ( ${ }^{*}$ indicates an uncertain position of the hydroxyl group). Right below (table)-substrate conversion and product formation compared to the next lower $\mathrm{rHinUPO}$ concentration tested: $\uparrow$ higher concentration of substrate/product, $\downarrow$ lower concentration of substrate/product-not detected.

The detection of 6-bromoindoxyl was impossible because of dissolved dioxygen $\left(\mathrm{O}_{2}\right)$ in the reaction solution. 6-Bromoindoxyl was indirectly quantified based on the amount of 6,6'-dibromoindigo, assuming that two equivalents of 6-bromoindoxyl are required to form one equivalent of 6,6'-dibromoindigo. In the presence of $100 \mathrm{mg} \mathrm{L}^{-1} \mathrm{rHinUPO}$, about $60 \%$ of the substrate was converted to 6,6'-dibromoindigo and $30 \%$ to 6-bromo-2-oxindole; in addition, precipitating polymerization products were formed. Even more enzyme (200 mg L $\mathrm{m}^{-1}$ or $300 \mathrm{mg} \mathrm{L}^{-1}$ ) resulted in only slightly higher amounts of $6,6^{\prime}$-dibromoindigo, but there was an increased formation of coupling products from 6-bromo-2-oxindole. The oxidation of 6-bromindole by rCciUPO $\left(25 \mathrm{mg} \mathrm{L}^{-1}\right)$ gave only $10 \%$ 6,6'-dibromoindigo and $80 \%$ 6-bromo-2-oxindole (the rest were again coupling products). Higher enzyme loads did not further change these percentages (data not shown).

\section{Discussion}

\subsection{Reaction Sequence and Products}

All tested UPOs oxidized indole and several halogenated derivatives (indigoids), albeit to varying degrees. A postulated general reaction scheme, including enzymatic and spontaneous steps, is given in Figure 8 (it applies to both unsubstituted and halogenated indoles). The indole molecule is oxidized in the first step to the corresponding indole 2,3-epoxide, which is a well-known reaction of this enzyme type [30,41-43]. Surprisingly, 2,3-epoxides opened apparently with quite different preference regarding the formation of 2-oxindole and indoxyl (3-oxindole), suggesting a directing influence of the respective 
UPO on epoxide opening. On the other hand, ring opening of epoxides formed by AaeUPO from naphthalene was reported to proceed spontaneously, independent of the $\mathrm{pH}$ [41]. Unlike naphthalene, indole is an aromatic heterocycle, whose inhomogeneous electron density distribution in the ring could influence epoxide opening, e.g., towards 2-oxindole formation. Alternately, a direct hydroxylation of the $\mathrm{C} 2$ or $\mathrm{C} 3$ position could be proposed (via $\mathrm{H}$-abstraction and oxygen rebound instead via epoxide formation), the extent of which would in fact be dependent of the particular enzyme. The next step involves the reaction of indoxyl (3-oxindole enol form) to the corresponding phenoxyl-like radical, which can proceed spontaneously in the presence of dioxygen $\left(\mathrm{O}_{2}\right)$ or may be facilitated by the peroxidative activity of UPO (causing one-electron oxidations). Two of these radicals, in their carbon-centered mesomeric form, then couple to leuco-indigo that in the last step oxidizes spontaneously to indigo. The simple fact that the in-situ dyeing process has been working may support this putative mechanism, along with the observation that-under micraerobic conditions-first the yellowish color of leuco-indigo and later the blue color of indigo appeared. It should be noted, in this context, that the chemical explanations for the formation of indigo are anything else than trivial and are still a subject of discussion $[23,44]$.

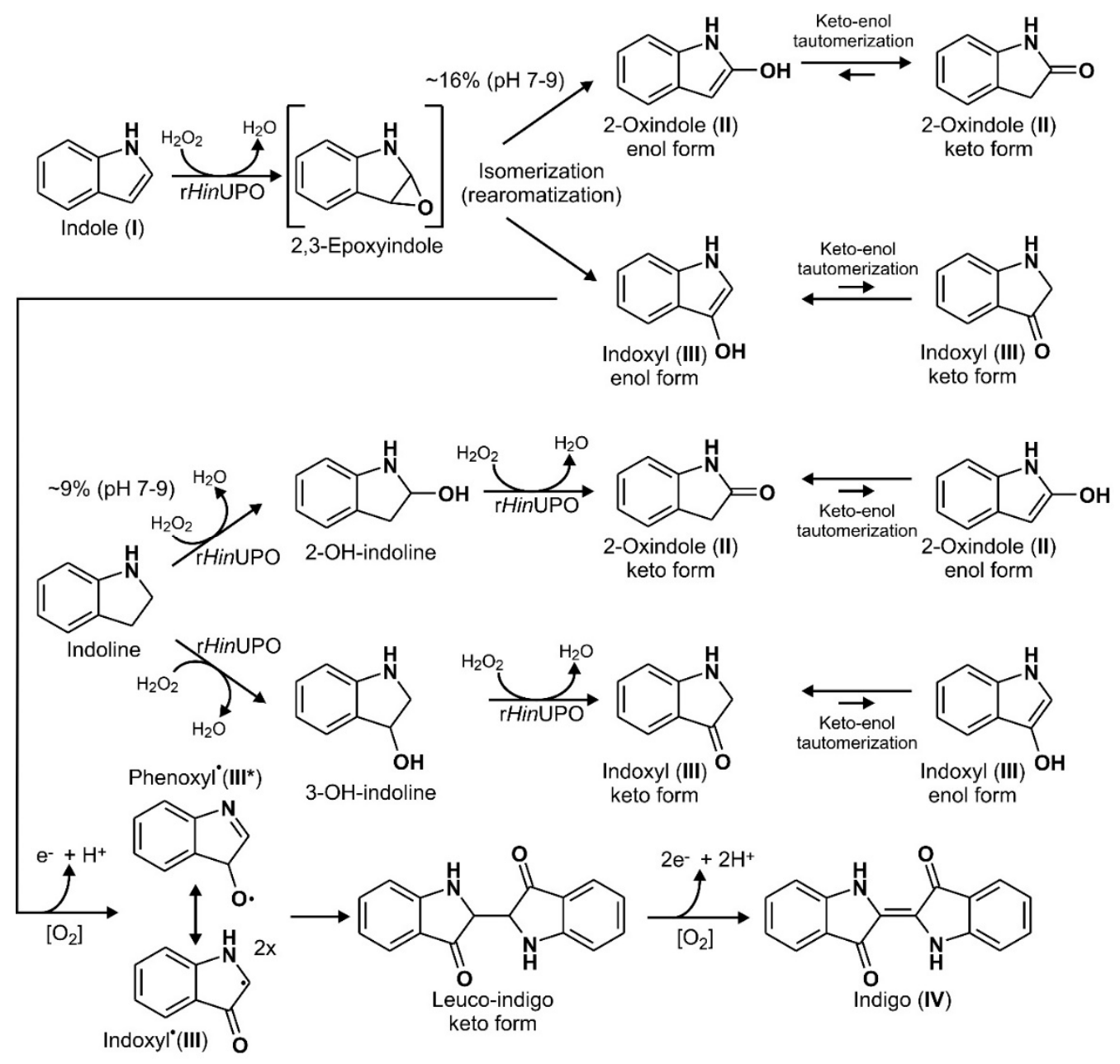

Figure 8. Postulated reaction sequences for the UPO-catalyzed formation of indigo from indole. Dashed arrows indicate putative multistep reactions; square brackets mark a postulated highly reactive epoxide intermediate (2,3-epoxyindole).

\subsection{Considerations for the Commercialization of Peroxygenase-Catalyzed Indigoid Synthesis}

The here presented small screening of different UPOs, revealed that the two enzymes originating from the ascomycete Humicola insolens and the basidiomycete Coprinopsis cinerea are suited best for the synthesis of the indigoid dyestuffs. Other biocatalytical approaches to indigo were developed in the past utilizing whole cell catalysis, enzymes or metalloporphyrin 
catalytic systems mimicking P450s [12,20,23,45-47]. Several obstacles have made a commercialization of these routes not feasible. This included low production yields, the expensive use of cofactors such as NADH, NADPH or FAD and complex enzyme cascades. The here reported integrated synthesis and dyeing system with UPOs has the advantages that it requires solely $\mathrm{H}_{2} \mathrm{O}_{2}$ as co-substrate and relies on a single enzyme. We have estimated that the total turnover number (TTN) reached in this study of around 1000 must be increased 50- to 100-fold before a commercialization can be attempted. UPOs showed, in the past, TTNs in that range and above towards other substrates, e.g., (wt) AaeUPO: ethylbenzene 43,000 [41]; toluene 39,200 [48], evolved rAaeUPO: ethylbenzene 400,000 [49], rHinUPO: isophorone 5600 [50]. To further increase total TTN, enzyme engineering and improved reaction design with careful control of $\mathrm{H}_{2} \mathrm{O}_{2}$ dosage will be important, as $\mathrm{H}_{2} \mathrm{O}_{2}$-driven heme destruction has been reported to impair UPO catalysis [51]. During the in-situ dyeing process applied here, we could already reduce enzyme inactivation by dosing diluted hydrogen peroxide in several portions (instead of adding one portion of concentrated $\mathrm{H}_{2} \mathrm{O}_{2}$ ).

In the course of synthesizing Tyrian purple, we made the observation that the end products (dyes) had different proportions of purple and blue pigments, depending on the enzyme used. Tyrian purple (absorption max $525 \mathrm{~nm}$ and $600 \mathrm{~nm}$ ) is a mix of indigo (absorption maximum/ $\lambda$ max: around $600 \mathrm{~nm}$ ), 6-bromoindigo and 6,6'-dibromoindigo (absorption $\lambda$ max $525 \mathrm{~nm}$ ), where 6,6'-dibromoindigo forms the major part. The ratio between indigo and $6,6^{\prime}$-dibromoindigo is dependent on solar radiation and its intensity during the drying of the fabric after the dyeing process, due to the phenomenon of photo-debromination [52,53].

Furthermore, the reaction must be optimized in regard to its water utilization; currently the maximum concentration of indole tested was $50 \mathrm{mM}\left(\sim 5.9 \mathrm{~g} \mathrm{~L}^{-1}\right)$. The concentration of substrate should ideally be between 50 and $100 \mathrm{~g} \mathrm{~L}^{-1}$, which is, in the current setup, impossible to reach, due to the limited solubility of indole in water and might require further use of solvents, which is expensive and would require additional downstream processing steps.

Practicable routes to indole have been known for over 140 years, after Emil Fischer invented the Fischer indole synthesis, and have only increased in scope and number since then [54,55]. The enzymatic procedure presented here is an opportunity for the dyeing industry to move away from aniline-contaminated and fossil-based indole and toward sustainable raw materials and gentle production processes [56]. This includes, of course, the green synthesis of indole from renewable resources [56]. Lastly, the formation of 2-oxindole as byproduct is currently not avoidable and it will eventually accumulate. In our study, we showed that different UPOs have different preferences regarding the formation of 2-oxindole. This suggests the targeted screening of more UPOs along with enzyme engineering to reduce (or even avoid) the formation of 2-oxindole and other undesired byproducts. On the other hand, 2-oxindole is a substance of interest for chemists as a small active molecule for syntheses, as well as a specific tyrosine kinase inhibitor with pharmaceutical relevance [57].

\subsection{Enzymatic Dyeing Process, of Interest for Textile Industry?}

Indigoid dyes are classical vat dyes. When these dyes, which are themselves insoluble, are applied, they have to be converted by reduction into an alkali-soluble form, the leucoindigo derivatives. Only these leuco-forms are capable of dyeing the cotton fibers, upon which they are then fixed and oxidized. Numerous chemicals and processes have been described to carry out the reduction. Sodium dithionite $\left(\mathrm{Na}_{2} \mathrm{~S}_{2} \mathrm{O}_{4}\right)$ is the most commonly used reducing agent for this purpose; hydroxyacetone is also used, but less frequently [58]. The repeated contact with the air dioxygen oxidizes leuco-indigo or its derivatives to stable bounded indigoid dyes. A negative fact in these processes is the impossibility to recycle the dye-reducing chemicals. Thus, the excess chemicals and their byproducts formed during the dyeing process find their way into the wastewater. Additionally, the reduction process requires elevated temperatures. 
Other proposed dyeing techniques include the reduction of indigo by indirect electrolysis [59]. Hydroxycarbonyls (such as glucose, acetoin or acetol) were also proposed as 'greener' reducing agents. However, higher temperatures and large amounts of sodium hydroxide are still required under such conditions [60]. There are also studies that used bacterial enzymes as reducing agent, for example, crude NADH-dependent reductases isolated from Bacillus subtilis with the ability for the reduction of indigo into its leuco-form. Still, the applied temperature was rather high $\left(55\right.$ to $\left.60^{\circ} \mathrm{C}\right)$, and the $\mathrm{pH}$ optima of these enzymes ranged between unfavorable $\mathrm{pH} 9.0$ and 11.0 [61]. An interesting neat approach includes the use of an immobilized $\beta$-glucosidase (from Aspergillus niger) to hydrolyze indican at $\mathrm{pH} 3.0$ to indoxyl under nitrogen atmosphere [62]. The dyeing process was reported to proceed via immersing of the cotton fabric in a prepared indoxyl solution and their subsequent exposition to ammonia vapor for a short time, resulting in rapid indigo dyeing. The major disadvantage of this process lies in the use of ammonia vapor.

We have shown in our study that UPOs and indole could be an alternative to conventional dyeing processes with indigoids. The proposed in-situ dyeing method is rather simple, does not require additional chemicals (except moderate amounts of $\mathrm{ACN}$ or another co-solvent) for dissolving the indole substrate, and hydrogen peroxide $\left(\mathrm{H}_{2} \mathrm{O}_{2}\right)$ that is fully consumed by the enzyme during the reactions. A further advantage is the moderate temperature (RT), at which the reactions are running. Most importantly, the dyeing process proposed here is independent of reducing agents, since it produces the dye 'online', which cuts down dye synthesis and dyeing to one step.

\subsection{Products for Medicine and Other Applications}

The use of indigo derivatives in pharmaceutical and medicinal applications is another interesting aspect of the use of peroxygenases. Indigo naturalis (also known as Qing-Dai) has been used in traditional Chinese medicine for centuries, and it is going to receive increasing attention in the treatment of inflammatory diseases [63,64]. In the literature, there are reports describing the use of indigo and Tyrian purple as substrates for the synthesis of potent protein kinase inhibitors [65]. Furthermore, indigoids have been found to possess a therapeutic value for a number of diseases, including Alzheimer, certain forms of cancer, and delayed hypersensitivity [65-67]. A totally different application of indigo and Tyrian purple is related to their semiconductor properties. Novel high-performance organic field-effect transistors with ambipolar charge transport can be produced from them in form of thin, highly-ordered, polymer films. In this context, indigoids act as functional and biodegradable nanomaterials with promising potential for 'green electronics' [68].

\section{Materials and Methods}

\subsection{Chemicals}

6-bromoindole and 5-chloroindole were obtained from Alfa Aesar/Fisher Scientific $\mathrm{GmbH}$ (Schwerte, Germany). All other chemicals were purchased from Sigma-Aldrich $\mathrm{GmbH}$ (Schnelldorf, Germany) in highest purity available.

\subsection{Enzymes}

The extracellular wild-type peroxygenase from Cyclocybe (Agrocybe) aegerita ((V. Brig.) Vizzini), AaeUPO (main isoform, 46 kDa; SEQ ID NO: 1 in WO2014/122109), was produced and purified as described previously [23]. The enzyme preparation was homogeneous by sodium dodecyl polyacrylamide gel electrophoresis (SDS-PAGE) and exhibited an A418/A280 ratio ( $R Z$ value) of 1.75. The specific activity of the AaeUPO preparation was $70 \mathrm{U} \mathrm{mg}^{-1}$, in which $1 \mathrm{U}$ represents the oxidation of $1 \mu \mathrm{mol}$ of veratryl alcohol (3,4-dimethoxybenzyl alcohol) to veratraldehyde (3,4-dimethoxybenzaldehyde) in $1 \mathrm{~min}$ at $23^{\circ} \mathrm{C}$. The recombinant peroxygenases from Coprinopsis cinerea ((Schaeff.) Redhead, Vilgalys \& Moncalvo), rCciUPO (SEQ ID NO: 2 in WO2014/122109) and from Humicola insolens (Cooney \& R. Emers.), rHinUPO (SEQ ID NO: 2 in WO 2013/021061), 
were recombinant wild-types, kindly provided by Novozymes A/S (Bagsværd, Denmark). All enzymes were applied as solutions.

\subsection{Enzyme Screening of Wild Types and Recombinantly Expressed Wild Types}

Typical reaction mixtures $(0.2-1.0 \mathrm{~mL})$ contained purified peroxygenase $\left(1.0-2.0 \mathrm{U} \mathrm{mL}^{-1}=0.04-0.08 \mu \mathrm{M}=0.014-0.028 \mathrm{mg} \mathrm{mL}^{-1}\right)$, substrate to be oxygenated (0.5-2.0 mM; stock solution $50 / 50 \mathrm{H}_{2} \mathrm{O} / \mathrm{ACN}=5 \%$ final concentration), and potassium phosphate buffer (PPB; $50 \mathrm{mM}, \mathrm{pH}$ 7.0). Reactions were started by the addition of $\mathrm{H}_{2} \mathrm{O}_{2}$ to a final amount of $2.0-5.0 \mathrm{mM}$ and stirred at room temperature over two hours.

\subsection{Quantification of Indigo Using Sulfonation}

After the reaction, the solution was centrifuged $(13000 \times g, 1 \mathrm{~h})$ and the supernatant removed for LC-MS analysis. The precipitated indigo was dried at $105{ }^{\circ} \mathrm{C}$ for $2 \mathrm{~h}$, followed by the addition of $400 \mu \mathrm{L} 96 \% \mathrm{H}_{2} \mathrm{SO}_{4}$. The sample was incubated in a thermostat for $10 \mathrm{~min}$ at $95^{\circ} \mathrm{C}$. After incubation, $1600 \mu \mathrm{L}$ deionized water was added and the absorbance of the sample immediately measured at $640 \mathrm{~nm}$. An indigo standard curve was prepared daily using commercially available indigo and the corresponding water-soluble indigo sulfonate accordingly as described above.

\subsection{Determination of $p H$ Dependence of rHinUPO Catalyzed Indigo Formation}

A selection of Britton-Robinson-buffered samples was prepared ranging from $\mathrm{pH}$ 2.0 to 11.0 and additionally a TRIS- $\mathrm{HCl}$ buffer of $\mathrm{pH} 9.0$ and $\mathrm{pH} 10.0 . \mathrm{H}_{2} \mathrm{O}_{2}(2.0 \mathrm{mM})$ was mixed with indole $(5.725 \mathrm{mM})$ in $5 \mathrm{mM}$ of the respective buffer. The reaction mixture was stripped for air using nitrogen gas $\left(\mathrm{N}_{2}\right)$ for $15 \mathrm{~min}$. The reaction was started by the addition of $0.01 \mathrm{mg} \mathrm{mL}^{-1}$ enzyme (rHinUPO). The total reaction volume was $10 \mathrm{~mL}$ and run for $1 \mathrm{~h}$ under constant nitrogen stripping. After the reaction, the mixture was stirred under aerobic conditions for $1 \mathrm{~h}$ to allow for full formation of indigo, followed by drawing a homogeneous sample of $1 \mathrm{~mL}$ and the indigo concentration was determined using the above described sulfonation method. Percentage values for indigo formation are shown as fractions of the limited substrate $\mathrm{H}_{2} \mathrm{O}_{2}$ and calculated according to the following mathematical Formula (1).

$$
\% \text { Indigo }=((\text { Indigo } \mathrm{mM} \times 2)) /\left(\mathrm{H}_{2} \mathrm{O}_{2} \mathrm{mM}\right)
$$

\subsection{Variant Generation for Rational Design Enzyme Library of rHinUPO}

Based on the homologues structure of Marasmius rotula (pdb5FUK), 83 variants of rHinUPO were designed. 4 methionine's were mutated to leucine's (pos. 19, 65, 148 and $165)$ to avoid potential oxidation of methionine. Tryptophane's (pos. 5, 117, 179, 183, 195) and phenylalanine's (pos 28,62,184), which could potentially be involved in long range electron transfer, were mutated to various residues - preferably as conservative as possible in order to reduce peroxidase activity on the protein surface. Potential $\mathrm{N}$-glycosylation sites (N52, N71, N106, N216) were mutated to avoid any interaction which the sugar might have with potential substrate. The residues in the two helixes flanking the active site (A55, A58, F62 and L151, I154, F154, G158, E159) were mutated to various residues to change the specific activity to various substrates (see Figure S7 of pdb5FUK) The rHinUPO variants were made by standard mutagenesis [69] and were transformed and produced in Aspergillus oryzae ((Ahlburg) E. Cohn) in standard MDU-2BP medium containing hemin [70]. The five variants that were chosen, based on the initial screening, were made using corresponding oligosmers (Table S1).

\subsection{Variant Screening in 96-Well Plate Assay}

Indole $(5.0 / 1.0 \mathrm{mM})$ was converted by $0.01 \mathrm{mg} \mathrm{mL}^{-1} \mathrm{rHinUPO}$ and variants thereof indicated with different numbers in 96-well plates with a total reaction volume of $160 \mu \mathrm{L}$. Reaction conditions were $5.0 \mathrm{mM}$ TRIS-HCl buffer ( $\mathrm{pH}$ 10.0), $2.0 \mathrm{mM} \mathrm{H}_{2} \mathrm{O}_{2}$, room temperature (RT) and shaking with $400 \mathrm{rpm}$ on a plate shaker. The reaction was started by 
the addition of $\mathrm{H}_{2} \mathrm{O}_{2}$ and stopped using $10 \mu \mathrm{L}$ of a 1:10 dilution of Terminox ${ }^{\circledR}$ Supreme (Novozymes A/S, a formulation with catalase activity) followed by shaking for $30 \mathrm{~min}$. Subsequently, $110 \mu \mathrm{L} 96 \% \mathrm{H}_{2} \mathrm{SO}_{4}$ was added and absorbance at $640 \mathrm{~nm}$ measured immediately. Quantification was performed by the usage of an indigo standard curve. The data given are average values of three technical replicates.

\subsection{Verification of Screening Hits under Different Atmospheres}

Indole $(5.725 \mathrm{mM})$ was mixed with $10.0 \mathrm{mM}$ TRIS-HCl buffer, $\mathrm{pH} 10.0$ and $2.0 \mathrm{mM}$ $\mathrm{H}_{2} \mathrm{O}_{2}$. In case of the micro-aerobic and air-saturated samples, the mixtures were flushed with nitrogen $\left(\mathrm{N}_{2}\right)$ and air $\left(21 \% \mathrm{O}_{2}, 78 \% \mathrm{~N}_{2}, 1 \%\right.$ trace gases), respectively for $15 \mathrm{~min}$ before the reaction was started by addition of $0.01 \mathrm{mg} \mathrm{mL}^{-1}$ enzyme. The reaction was run for $1 \mathrm{~h}$ at room temperature and under continued gas flushing for the micro-aerobic and air-saturated samples. All reaction solutions were mixed using magnetic stirring. After the reaction, the samples were stirred open for $1 \mathrm{~h}$ and indigo concentration was determined using the sulfonation method described above.

\subsection{Proof of Indoxyl Formation}

The reaction mixtures were prepared corresponding to typical reaction conditions described above. Additionally, helium $(\mathrm{He})$ was flushed into the reaction mixtures before and during the reaction to permanently generate micro-aerobic conditions (dioxygen stripping). The reactions were stopped by the addition of sodium azide $\left(\mathrm{NaN}_{3}\right)$ after 1,5 , or $10 \mathrm{~min}$ and afterwards analyzed with HPLC-IT-MS. The indoxyl standard was freshly prepared by hydrolyzing indoxyl acetate with an esterase from Mucor miehei (Cooney \& R. Emers.) (Sigma-Aldrich GmbH, Schnelldorf, Germany) under almost anoxic conditions. In order to prove the ability of indoxyl to react with 2-oxindole, a corresponding reaction solution was prepared, but with the addition of $500 \mu \mathrm{M} 2$-oxindole.

\subsection{Comparison of UPO-Catalyzed Conversion of 5-Bromoindol and 5-Bromoindoline}

The reaction mixtures $(1.0 \mathrm{~mL})$ contained purified peroxygenases $(\mathrm{rHinUPO}, \mathrm{Aae} \mathrm{UPO}$ and $\mathrm{rCciUPO}$ ) at a final concentration of $35 \mathrm{mg} \mathrm{L}^{-1}$ and a substrate concentration of $400 \mu \mathrm{M}$ in $5 \% \mathrm{ACN}$ and $50 \mathrm{mM}$ PPB (pH 7.0). Reactions were started by adding $\mathrm{H}_{2} \mathrm{O}_{2}(800 \mu \mathrm{M}$ in the case of 5-bromoindoline and $400 \mu \mathrm{M}$ in the case of 5-bromoindole) and run for at least $2 \mathrm{~h}$ at $23^{\circ} \mathrm{C}$.

\subsection{In-Situ Dyeing Pre-Study}

For validation of the fundamental feasibility of an in situ dyeing process, the typical reaction setup (see above) was used, with the addition of cotton fabric pieces before the reactions were started by dosage of $\mathrm{H}_{2} \mathrm{O}_{2}$. After the start (i.e., 15 min after $\mathrm{H}_{2} \mathrm{O}_{2}$ addition), the fabric pieces were removed, washed with tap water and dried on air.

\subsection{LC-MS Analysis}

Products of enzymatic catalysis were analyzed by high performance liquid chromatography (HPLC) using an Agilent Series 1200 instrument equipped with a diode array detector (DAD) and an electrospray ionization mass spectrometer (ESI-MS) (Agilent Technologies Deutschland $\mathrm{GmbH}$, Böblingen, Germany). Unless otherwise stated, reverse phase chromatography of reaction mixtures was performed on a Luna C18 column ( $2 \mathrm{~mm}$ diameter by $250 \mathrm{~mm}$ length, $3 \mu \mathrm{m}$ particle size, Phenomenex, Aschaffenburg, Germany), which was eluted at $0.2 \mathrm{~mL} \mathrm{~min}-1$ and $40{ }^{\circ} \mathrm{C}$ with aqueous $0.01 \%(v / v)$ formate (adjusted to $\mathrm{pH} 3.5$ with an aqueous solution of ammonia)/acetonitrile (ACN), 95:5 for $5 \mathrm{~min}$, followed by a 15 min linear gradient to $100 \% \mathrm{ACN}$.

Mass spectrometric measurements were made in positive or negative ESI modes in a mass range from 70 to 900 (step size 0.1 , drying gas temperature $350{ }^{\circ} \mathrm{C}$, capillary voltage $4000 \mathrm{~V}$ for positive mode and $5500 \mathrm{~V}$ for negative mode). The reaction products were 
identified relative to authentic standards, based on their retention times, UV-Vis spectra, and mass ions $[\mathrm{M}+\mathrm{H}]^{+}$or $[\mathrm{M}-\mathrm{H}]^{-}$.

\subsection{HPLC-IT-MS Analysis}

Indoxyl formation was verified by high performance liquid chromatography (HPLC) as described above; however, the device was equipped with an ion trap analyzer (Agilent 6310). As stationary phase, a Kinetex PFP column ( $2.1 \mathrm{~mm}$ diameter by $50 \mathrm{~mm}$ length, $5 \mu \mathrm{m}$ particle size, Phenomenex, Aschaffenburg, Germany) was used and eluted at $0.7 \mathrm{~mL} \mathrm{\textrm {min } ^ { - 1 }}$ and $40{ }^{\circ} \mathrm{C}$ with aqueous $0.01 \mathrm{vol} \%$ formate (adjusted to $\mathrm{pH} 3.5$ )/ $\mathrm{ACN}, 95: 5$ for $0.5 \mathrm{~min}$, followed by a 6 min linear gradient to $90 \%$ ACN.

Mass spectrometric measurements were carried out in the positive ESI mode with a mass range from 50 to 500 , a drying gas temperature of $365^{\circ} \mathrm{C}$ and a capillary voltage of $4000 \mathrm{~V}$.

The conversion of 5-bromoindole and 5-bromoindolene was determined using a Phenylhexyl stationary phase (Kinetex, $2.6 \mu \mathrm{m}, 100 \AA, 75 \times 2.1 \mathrm{~mm}$ from Phenomenex) and a mobile phase consisting of $0.01 \%$ formic acid and ACN. The gradient was as follows: $5 \% \mathrm{ACN}$ for $2 \mathrm{~min}$, within $6 \mathrm{~min}$ increase to $50 \% \mathrm{ACN}$, hold for 2 min at a flow rate of $0.6 \mathrm{~mL} \mathrm{~min}^{-1}$ and a temperature of $40^{\circ} \mathrm{C}$.

\subsection{Determination of the Reaction Time Course}

The reaction time course experiments were carried out in glass cuvettes $\left(1 \mathrm{~mL}, 23^{\circ} \mathrm{C}\right)$ that contained enzyme $\left(0.003,0.006,0.012,0.025 \mathrm{mg} \mathrm{mL}^{-1} \mathrm{rHinUPO}\right.$ or $0.0125,0.025$, $\left.0.05,0.11 \mathrm{mg} \mathrm{mL}^{-1} \mathrm{rCciUPO}\right), \mathrm{PPB}(50 \mathrm{mM}, \mathrm{pH} 7.0)$ and $2.0 \mathrm{mM}$ 6-bromoindole. The measurements and reactions were started with $2.0 \mathrm{mM} \mathrm{H}_{2} \mathrm{O}_{2}$ and recorded for $15 \mathrm{~min}$ at $530 \mathrm{~nm}$ with a Cary $50 \mathrm{UV} /$ visible spectrophotometer using the kinetics software (Agilent). In addition, the Tyrian purple formation was also recorded in the scan kinetic mode for $15 \mathrm{~min}$ using the same spectrophotometer $\left(0.025 \mathrm{mg} \mathrm{mL}^{-1} \mathrm{rHinUPO}\right.$ or rCciUPO).

\subsection{Product Purification}

Completed reaction mixtures were stored for at least $12 \mathrm{~h}$ at room temperature for crystallization and precipitation of indigoids. Afterwards all samples were centrifuged in reaction tubes (Eppendorf 5424R at 15,700 $\times g$ ) or in falcon tubes (samples from scale up experiments; Beckman Coulter Allegra 64R, rotor C0650, at 10,400 $\times g$ ). The supernatants were discarded and the solid phases washed threefold using a mixture of water and ACN $(50 / 50 \% v / v)$ and repeated centrifugation. Finally, the solid phases were dried in a drying cabinet at $50{ }^{\circ} \mathrm{C}$.

\subsection{Synthesis of 6,6'-Dibromoindigo}

6,6'-Dibromoindigo served as a standard and was synthesized from 4-bromo-2-nitrobenzaldehyde using a modified method according to Sachs and Kempf [14]. $2 \mathrm{~g}$ of 4-bromo-2-nitrobenzaldehyde was dissolved in $100 \mathrm{~mL}$ acetone and $100 \mathrm{~mL}$ of $1 \mathrm{M} \mathrm{NaOH}$ was added. The reaction mixture was boiled for one hour. Afterwards the sample was dried with a rotary evaporator and finally washed three times alternately with water and acetone. The yield of the product was $1.26 \mathrm{~g}$ and the purity was proven by LC-MS analysis.

\subsection{Quantification of Tyrian Purple}

To increase the solubility of Tyrian purple, it was sulfonated. For this purpose, an appropriate reaction mixture was transferred into a $1.5-\mathrm{mL}$ reaction tube, centrifuged $(16,100 \mathrm{rcf}, 5 \mathrm{~min})$ and the supernatant was separated. The precipitate was dried at $50{ }^{\circ} \mathrm{C}$ in a drying cabinet for $15 \mathrm{~min}$. Subsequently, $200 \mu \mathrm{L}$ of sulfuric acid $(20 \mathrm{wt} \%)$ was added and dried again for $15 \mathrm{~min}$ at $90{ }^{\circ} \mathrm{C}$. Solutions with different concentrations of 6,6'-dibromoindigo were prepared accordingly and served as calibrant. All samples were filled up to $1 \mathrm{~mL}$ with distilled water and transferred to a 48-well plate (Cellstar, Greiner Bio One, Frickenhausen, Germany). Finally, the absorbance was measured at $600 \mathrm{~nm}$ using a multi plate reader (Infinity M 200, Tecan, Crailsheimm, Germany, Magellan 7.2 software). 


\subsection{Common Chemical Dyeing by Application of Enzymatically Synthesized Dyes}

For the chemical dyeing experiment with products of the enzymatic reaction, we applied established recipes. $625 \mathrm{mg}$ sodium dithionite and $300 \mathrm{mg} \mathrm{NaOH}$ were put into $5 \mathrm{~mL}$ tap water supplemented with solid dye and heated to $80^{\circ} \mathrm{C}$ in a combined orbital linear shaking water bath (OLS 200, Grant Instruments Cambridge, Shepreth, UK). After reduction to the corresponding leuco-indigo derivatives, the solution was transferred to boiling water with a slice of cotton cloth, boiled for $5 \mathrm{~min}$ and dried. After all, the dried cotton fabrics were washed in warm water with detergent for some minutes.

\subsection{Scaled up In-Situ Dyeing}

The total reaction volume was increased to $10 \mathrm{~L}$ in a stainless steel barrel $(25 \mathrm{~L})$ installed on a laboratory shaker. For in situ dyeing, $5 \mathrm{~L}$ of $100 \mathrm{mM} \mathrm{PPB}(\mathrm{pH} 7.0)$ was filled into the barrel and $2 \mathrm{~g}$ of 6-bromoindole dissolved in $500 \mathrm{~mL} \mathrm{50 \%} \mathrm{ACN} \mathrm{was} \mathrm{added.} \mathrm{The}$ reaction solution was filled up to $10 \mathrm{~L}$ with tap water deducting the volume of enzyme solution and $\mathrm{H}_{2} \mathrm{O}_{2}$. The shaker was used between 150 to $180 \mathrm{rpm}$. After 5 min shaking, about $200 \mathrm{~g}$ cotton fabric was added to the reaction liquid prior to the addition of $\mathrm{H}_{2} \mathrm{O}_{2}$ that initiated the dyeing reaction. Afterwards $9 \mathrm{mg}$ rCciUPO dissolved in $500 \mathrm{~mL}$ water was added to a final concentration of $0.9 \mu \mathrm{g} \mathrm{mL}^{-1}$. The dying process was started by the addition of $\mathrm{H}_{2} \mathrm{O}_{2}$ (12.5 mmol in $\left.250 \mathrm{~mL}\right)$ and continued by three further dosages every 30 min leading to a final amount of $50 \mathrm{mmol}_{2} \mathrm{O}_{2}$. After two hours, the cotton fabric was removed from the reactor, washed with tap water and dried at room temperature. We illustrate the complete dyeing procedure in the results section above.

\section{Conclusions}

Here we report on a simple and environmentally friendly method for the biocatalytic synthesis of indigoid dyes and the concomitant in-situ dyeing of cotton fabrics. Experiments under micro-aerobic conditions proved that dye formation occurs via oxidation of indole to indoxyl as reactive indigo precursor. The use of recombinant UPOs in the presence of low concentrations of organic solvents and hydrogen peroxide at room temperature allows for avoiding multistep syntheses, reductants, high-energy consumption and molecular transport problems. Thus, the UPO-indole system creates a promising alternative to established chemical methods, which, of course, will have been optimized and scaled-up in the future.

\section{Patents}

Herold-Majumdar, O., Poraj-Kobielska, M., Tovborg, M., Lund, H., Hofrichter, M.: Enzymatic preparation of indigo dyes and in situ dyeing process, 2017, WO2018002379A2.

Supplementary Materials: The following are available online at https:/ /www.mdpi.com/article/ 10.3390/catal11121495/s1, Table S1: Applied oligomers for rHinUPO mutants, Figure S1: HPLC elution profiles of micro-aerobic reaction solutions, Figure S2: Mass and UV-Vis spectra of indole and several oxidation products, Figure S3: HPLC elution profiles of a reaction solutions, Figure S4: Influence of the $\mathrm{pH}$ on the conversion of indole by $\mathrm{rHinUPO}$, Figure S5: Photograph of a reader plate, in which 5-bromoindoline and 5-bromoindole were converted by $\mathrm{rHinUPO}, A a e \mathrm{UPO}$ and rCciUPO at different $\mathrm{pH}$ values, Figure S6: Vis-spectra of dyes produced from 5-bromoindoline and 5-bromoindole by $\mathrm{rHinUPO}, A a e \mathrm{UPO}$ and $\mathrm{rCciUPO}$ at different $\mathrm{pH}$ values, Figure S7: Structure of MroUPO (pdb5FUK) with flanking hellixes

Author Contributions: Conceptualization, M.P.-K. and R.U.; methodology, M.P.-K., R.U. and O.M.H.-M.; investigation, R.U. and M.P.-K.; resources, M.P.-K. and O.M.H.-M.; data curation, R.U., M.P.-K. and O.M.H.-M.; writing—original draft preparation, M.P.-K., R.U. and O.M.H.-M.; writing-review and editing, M.H.; visualization, R.U. and M.P.-K.; supervision, M.H.; project administration, M.H.; funding acquisition, M.H. and J.V. All authors have read and agreed to the published version of the manuscript.

Funding: This work was supported by the European Union project INDOX (KBBE-2013-7-613549). 
Data Availability Statement: Full data sets are available either in the Supplementary Materials (see the main text) or upon request from the corresponding author.

Acknowledgments: We thank Henrik Lund+ (Novozymes A/S) and René Jarling (Carl von Ossietzky University of Oldenburg) for the useful discussions. We would like to thank Betina Suldvart (Novozymes A/S) for technical assistance.

Conflicts of Interest: The authors declare no conflict of interest. The funders had no role in the design of the study; in the collection, analyses, or interpretation of data; in the writing of the manuscript, or in the decision to publish the results.

$\begin{array}{ll}\text { Abbreviations } \\ \text { UPO } & \text { unspecific peroxygenase } \\ \text { PPB } & \text { potassium phosphate buffer } \\ \text { Hin } & \text { Humicola insolens } \\ \text { Aae } & \text { Agrocybe aegerita } \\ \text { Cci } & \text { Coprinopsis cinerea } \\ \text { ACN } & \text { acetonitrile } \\ \text { HPLC-IT-MS } & \text { high performance liquid chromatography/ion trap mass spectrometry } \\ \text { LRET } & \text { long range electron transfer. }\end{array}$

\section{References}

1. Stieglitz, R.R. The Minoan origin of Tyrian purple. Biblic. Archaeol. 1994, 57, 46-54. [CrossRef]

2. Wolk, J.L.; Frimer, A.A. Preparation of Tyrian purple (6,6'-Dibromoindigo): Past and present. Molecules $2010,15,5473$. [CrossRef] [PubMed]

3. Friedländer, P. Über den Farbstoff des antiken Purpurs aus Murex brandaris. Ber. Dtsch. Chem. Ges. 1909, 42, 765-770. [CrossRef]

4. Cooksey, C. Tyrian purple: 6,6'-dibromoindigo and related compounds. Molecules 2001, 6, 736-769. [CrossRef]

5. Gillam, E.M.J.; Notley, L.M.; Cai, H.; De Voss, J.J.; Guengerich, F.P. Oxidation of indole by cytochrome P450 enzymes. Biochemistry 2000, 39, 13817-13824. [CrossRef]

6. Hsu, T.M.; Welner, D.H.; Russ, Z.N.; Cervantes, B.; Prathuri, R.L.; Adams, P.D.; Dueber, J.E. Employing a biochemical protecting group for a sustainable indigo dyeing strategy. Nat. Chem. Biol. 2018, 14, 256-261. [CrossRef]

7. Huisgen, R. Adolf von Baeyer's scientific achievements-A legacy. Angew. Chem. Int. Ed. Engl. 1986, 25, 297-311. [CrossRef]

8. Heumann, K. Neue Synthesen des Indigos und verwandter Farbstoffe. Ber. Dtsch. Chem. Ges. 1890, 23, 3431-3435. [CrossRef]

9. Steingruber, E. Indigo and indigo colorants. In Ullmann's Encyclopedia of Industrial Chemistry; Wiley-VCH: Weinheim, Germany, 2012; pp. 55-63.

10. Schmidt, H. Indigo-100 Jahre industrielle Synthese. Chem. Unserer Zeit 1997, 31, 121-128. [CrossRef]

11. Russell, G.A.; Kaupp, G. Reactions of resonance stabilized carbanions. XXXI. Oxidation of carbanions. 4. Oxidation of indoxyl to indigo in basic solution. J. Am. Chem. Soc. 1969, 91, 3851-3859. [CrossRef]

12. Rebelo, S.L.H.; Linhares, M.; Simões, M.M.Q.; Silva, A.M.S.; Neves, M.G.P.M.S.; Cavaleiro, J.A.S.; Freire, C. Indigo dye production by enzymatic mimicking based on an iron(III)porphyrin. J. Catal. 2014, 315, 33-40. [CrossRef]

13. Zollinger, H. Color Chemistry: Syntheses, Properties, and Applications of Organic Dyes and Pigments, 3rd ed.; Wiley-VCH: Weinheim, Germany, 2003; p. 637.

14. Sachs, F.; Kempf, R. Ueber p-Halogen-o-Nitrobenzaldehyde. Ber. Dtsch. Chem. Ges. 1903, 36, 3299-3303. [CrossRef]

15. Baeyer, A.; Drewsen, V. Darstellung von Indigblau aus Orthonitrobenzaldehyd. Ber. Dtsch. Chem. Ges. 1882, 15, 2856-2864. [CrossRef]

16. Sachs, F.; Sichel, E. Ueber p-substituirte o-Nitrobenzaldehyde. Ber. Dtsch. Chem. Ges. 1904, 37, 1861-1874. [CrossRef]

17. Wolk, J.L.; Frimer, A.A. A simple, safe and efficient synthesis of Tyrian purple (6,6'-dibromoindigo). Molecules $2010,15,5561$. [CrossRef] [PubMed]

18. Parette, R.; McCrindle, R.; McMahon, K.S.; Pena-Abaurrea, M.; Reiner, E.; Chittim, B.; Riddell, N.; Voss, G.; Dorman, F.L.; Pearson, W.N. Halogenated indigo dyes: A likely source of 1,3,6,8-tetrabromocarbazole and some other halogenated carbazoles in the environment. Chemosphere 2015, 127, 18-26. [CrossRef]

19. Kohlhaupt, R.; Bergmann, U. Purification of Indigo. U.S. Patent 5424453A, 14 June 1993.

20. Ensley, B.; Ratzkin, B.; Osslund, T.; Simon, M.; Wackett, L.; Gibson, D. Expression of naphthalene oxidation genes in Escherichia coli results in the biosynthesis of indigo. Science 1983, 222, 167-169. [CrossRef]

21. Mouri, T.; Michizoe, J.; Ichinose, H.; Kamiya, N.; Goto, M. A recombinant Escherichia coli whole cell biocatalyst harboring a cytochrome P450cam monooxygenase system coupled with enzymatic cofactor regeneration. Appl. Microbiol. Biotechnol. 2006, 72, 514-520. [CrossRef]

22. Carredano, E.; Karlsson, A.; Kauppi, B.; Choudhury, D.; Parales, R.E.; Parales, J.V.; Lee, K.; Gibson, D.T.; Eklund, H.; Ramaswamy, S. Substrate binding site of naphthalene 1,2-dioxygenase: Functional implications of indole binding. J. Mol. Biol. 2000, 296, 701-712. [CrossRef] [PubMed] 
23. Fabara, A.N.; Fraaije, M.W. An overview of microbial indigo-forming enzymes. Appl. Microbiol. Biotechnol. 2020, 104, 925-933. [CrossRef]

24. Ullrich, R.; Nüske, J.; Scheibner, K.; Spantzel, J.; Hofrichter, M. Novel haloperoxidase from the agaric basidiomycete Agrocybe aegerita oxidizes aryl alcohols and aldehydes. Appl. Environ. Microbiol. 2004, 70, 4575-4581. [CrossRef]

25. Ullrich, R.; Hofrichter, M. The haloperoxidase of the agaric fungus Agrocybe aegerita hydroxylates toluene and naphthalene. FEBS Lett. 2005, 579, 6247-6250. [CrossRef]

26. Gröbe, G.; Ullrich, R.; Pecyna, M.J.; Kapturska, D.; Friedrich, S.; Hofrichter, M.; Scheibner, K. High-yield production of aromatic peroxygenase by the agaric fungus Marasmius rotula. AMB Express 2011, 1, 31. [CrossRef]

27. Ullrich, R.; Poraj-Kobielska, M.; Scholze, S.; Halbout, C.; Sandvoss, M.; Pecyna, M.J.; Scheibner, K.; Hofrichter, M. Side chain removal from corticosteroids by unspecific peroxygenase. J. Inorg. Biochem. 2018, 183, 84-93. [CrossRef]

28. Anh, D.H.; Ullrich, R.; Benndorf, D.; Svatoś, A.; Muck, A.; Hofrichter, M. The coprophilous mushroom Coprinus radians secretes a haloperoxidase that catalyzes aromatic peroxygenation. Appl. Environ. Microbiol. 2007, 73, 5477-5485. [CrossRef]

29. Kiebist, J.; Schmidtke, K.-U.; Zimmermann, J.; Kellner, H.; Jehmlich, N.; Ullrich, R.; Zänder, D.; Hofrichter, M.; Scheibner, K. A peroxygenase from Chaetomium globosum catalyzes the selective oxygenation of testosterone. ChemBioChem 2017, 18, 563-569. [CrossRef]

30. Kluge, M.; Ullrich, R.; Dolge, C.; Scheibner, K.; Hofrichter, M. Hydroxylation of naphthalene by aromatic peroxygenase from Agrocybe aegerita proceeds via oxygen transfer from $\mathrm{H}_{2} \mathrm{O}_{2}$ and intermediary epoxidation. Appl. Microbiol. Biotechnol. 2009, 81, 1071-1076. [CrossRef]

31. Bassanini, I.; Ferrandi, E.E.; Vanoni, M.; Ottolina, G.; Riva, S.; Crotti, M.; Brenna, E.; Monti, D. Peroxygenase-catalyzed enantioselective sulfoxidations. Eur. J. Org. Chem. 2017, 47, 7186-7189. [CrossRef]

32. Aranda, E.; Kinne, M.; Kluge, M.; Ullrich, R.; Hofrichter, M. Conversion of dibenzothiophene by the mushrooms Agrocybe aegerita and Coprinellus radians and their extracellular peroxygenases. Appl. Microbiol. Biotechnol. 2008, 82, 1057-1066. [CrossRef]

33. Kinne, M.; Poraj-Kobielska, M.; Ralph, S.A.; Ullrich, R.; Hofrichter, M.; Hammel, K.E. Oxidative cleavage of diverse ethers by an extracellular fungal peroxygenase. J. Biol. Chem. 2009, 284, 29343-29349. [CrossRef]

34. Kiebist, J.; Holla, W.; Heidrich, J.; Poraj-Kobielska, M.; Sandvoss, M.; Simonis, R.; Gröbe, G.; Atzrodt, J.; Hofrichter, M.; Scheibner, K. One-pot synthesis of human metabolites of SAR548304 by fungal peroxygenases. Bioorganic Med. Chem. 2015, 23, 4324-4332. [CrossRef]

35. Olmedo, A.; Río, J.C.d.; Kiebist, J.; Ullrich, R.; Hofrichter, M.; Scheibner, K.; Martínez, A.T.; Gutiérrez, A. Fatty acid chain shortening by a fungal peroxygenase. Chem. A Eur. J. 2017, 23, 16985-16989. [CrossRef] [PubMed]

36. Kinne, M.; Poraj-Kobielska, M.; Aranda, E.; Ullrich, R.; Hammel, K.E.; Scheibner, K.; Hofrichter, M. Regioselective preparation of 5-hydroxypropranolol and 4'-hydroxydiclofenac with a fungal peroxygenase. Bioorganic Med. Chem. Lett. 2009, 19, 3085-3087. [CrossRef] [PubMed]

37. Poraj-Kobielska, M.; Kinne, M.; Ullrich, R.; Scheibner, K.; Kayser, G.; Hammel, K.E.; Hofrichter, M. Preparation of human drug metabolites using fungal peroxygenases. Biochem. Pharmacol. 2011, 82, 789-796. [CrossRef] [PubMed]

38. Kiebist, J.; Hofrichter, M.; Zuhse, R.; Scheibner, K. Oxyfunctionalization of pharmaceuticals by fungal peroxygenases. In Pharmaceutical Biocatalysis: Chemoenzymatic Synthesis of Active Pharmaceutical Ingredients; Grunwald, P., Grunwald, P., Eds.; Pan Stanford Series on Biocatalysis; Jenny Stanford Publishing: Singapore, 2019; Volume 5.

39. Hofrichter, M.; Ullrich, R. Oxidations catalyzed by fungal peroxygenases. Curr. Opin. Chem. Biol. 2014, 19, 116-125. [CrossRef] [PubMed]

40. Ullrich, R.; Karich, A.; Hofrichter, M. Fungal peroxygenases-A versatile tool for biocatalysis. In Encyclopedia of Mycology; Zaragoza, Ó., Casadevall, A., Eds.; Elsevier: Oxford, UK, 2021; pp. 260-280.

41. Kluge, M.; Ullrich, R.; Scheibner, K.; Hofrichter, M. Stereoselective benzylic hydroxylation of alkylbenzenes and epoxidation of styrene derivatives catalyzed by the peroxygenase of Agrocybe aegerita. Green Chem. 2012, 14, 440-446. [CrossRef]

42. Karich, A.; Kluge, M.; Ullrich, R.; Hofrichter, M. Benzene oxygenation and oxidation by the peroxygenase of Agrocybe aegerita. AMB Express 2013, 3, 5. [CrossRef]

43. González-Benjumea, A.; Marques, G.; Herold-Majumdar, O.M.; Kiebist, J.; Scheibner, K.; del Río, J.C.; Martínez, A.T.; Gutiérrez, A. High epoxidation yields of vegetable oil hydrolyzates and methyl esters by selected fungal peroxygenases. Front. Bioeng. Biotechnol. 2021, 8, 1470. [CrossRef]

44. Sánchez-Viesca, F.; Gómez, R. On the Baeyer-Emmerling synthesis of Indigo. World J. Org. Chem. 2018, 6, 6-12.

45. Murdock, D.; Ensley, B.D.; Serdar, C.; Thalen, M. Construction of metabolic operons catalyzing the de novo biosynthesis of indigo in Escherichia coli. BioTechnology 1993, 11, 381-386. [CrossRef]

46. McClay, K.; Boss, C.; Keresztes, I.; Steffan, R.J. Mutations of Toluene-4-monooxygenase that alter regiospecificity of indole oxidation and lead to production of novel indigoid pigments. Appl. Environ. Microbiol. 2005, 71, 5476-5483. [CrossRef]

47. Li, Q.-S.; Schwaneberg, U.; Fischer, P.; Schmid, R.D. Directed evolution of the fatty-acid hydroxylase P450 BM-3 into an indole-hydroxylating catalyst. Chem. Eur. J. 2000, 6, 1531-1536. [CrossRef]

48. Churakova, E.; Kluge, M.; Ullrich, R.; Arends, I.; Hofrichter, M.; Hollmann, F. Specific photobiocatalytic oxyfunctionalization reactions. Angew. Chem. Int. Ed. 2011, 50, 10716-10719. [CrossRef]

49. Horst, A.E.W.; Bormann, S.; Meyer, J.; Steinhagen, M.; Ludwig, R.; Drews, A.; Ansorge-Schumacher, M.; Holtmann, D. Electroenzymatic hydroxylation of ethylbenzene by the evolved unspecific peroxygenase of Agrocybe aegerita. J. Mol. Catal. B Enzym. 2016, 133, S137-S142. [CrossRef] 
50. Aranda, C.; Municoy, M.; Guallar, V.; Kiebist, J.; Scheibner, K.; Ullrich, R.; del Río, J.C.; Hofrichter, M.; Martínez, A.T.; Gutiérrez, A. Selective synthesis of 4-hydroxyisophorone and 4-ketoisophorone by fungal peroxygenases. Catal. Sci. Technol. 2019, 9, 1398-1405. [CrossRef]

51. Karich, A.; Scheibner, K.; Ullrich, R.; Hofrichter, M. Exploring the catalase activity of unspecific peroxygenases and the mechanism of peroxide-dependent heme destruction. J. Mol. Catal. B Enzym. 2016, 134, 238-246. [CrossRef]

52. Ramig, K.; Islamova, A.; Scalise, J.; Karimi, S.; Lavinda, O.; Cooksey, C.; Vasileiadou, A.; Karapanagiotis, I. The effect of light and dye composition on the color of dyeings with indigo, 6-bromoindigo, and 6,6'-dibromoindigo, components of Tyrian purple. Struct. Chem. 2017, 28, 1553-1561. [CrossRef]

53. Naegel, L.C.A.; Cooksey, C.J. Tyrian Purple from marine muricids, especially from Plicopurpura pansa (Gould, 1853). J. Shellfish Res. 2002, 21, 193-200.

54. Fischer, E.; Jourdan, F. Ueber die Hydrazine der Brenztraubensäure. Ber. Dtsch. Chem. Ges. 1883, 16, 2241-2245. [CrossRef]

55. Taber, D.F.; Tirunahari, P.K. Indole synthesis: A review and proposed classification. Tetrahedron 2011, 67, 7195-7210. [CrossRef]

56. Wang, P.; Arza, C.R.; Zhang, B. Indole as a new sustainable aromatic unit for high quality biopolyesters. Polym. Chem. 2018, 9 , 4706-4710. [CrossRef]

57. Buzzetti, F.; Longo, A.; Colombo, M. 2-Oxindole Compounds which Have Useful Tyrosine Kinase Activity. U.S. Patent 5488057A, 23 August 1994.

58. Marte, W.; Rys, P. Dyeing and Printing of Cellulosic Fibre Materials with Vat Dyes with Mono- or Di-Hydroxyacetone as Reducing Agent. U.S. Patent 4950306-A, 27 July 1989.

59. Bechtold, T.; Burtscher, E.; Turcanu, A.; Bobleter, O. Dyeing behavior of Indigo reduced by indirect electrolysis. Text. Res. J. 1997, 67, 635-642. [CrossRef]

60. Meksi, N.; Ben Ticha, M.; Kechida, M.; Mhenni, M.F. Using of ecofriendly $\alpha$-hydroxycarbonyls as reducing agents to replace sodium dithionite in indigo dyeing processes. J. Clean. Prod. 2012, 24, 149-158. [CrossRef]

61. Božič, M.; Kokol, V.; Guebitz, G.M. Indigo dyeing of polyamide using enzymes for dye reduction. Text. Res. J. 2009, 79, 895-907. [CrossRef]

62. Song, J.; Imanaka, H.; Imamura, K.; Kajitani, K.; Nakanishi, K. Development of a highly efficient indigo dyeing method using indican with an immobilized $\beta$-glucosidase from Aspergillus niger. J. Biosci. Bioeng. 2010, 110, 281-287. [CrossRef] [PubMed]

63. Lin, Y.-K.; See, L.-C.; Huang, Y.-H.; Chang, Y.-C.; Tsou, T.-C.; Lin, T.-Y.; Lin, N.-L. Efficacy and safety of Indigo naturalis extract in oil (Lindioil) in treating nail psoriasis: A randomized, observer-blind, vehicle-controlled trial. Phytomedicine 2014, 21, 1015-1020. [CrossRef]

64. Lee, C.-L.; Wang, C.-M.; Hu, H.-C.; Yen, H.-R.; Song, Y.-C.; Yu, S.-J.; Chen, C.-J.; Li, W.-C.; Wu, Y.-C. Indole alkaloids indigodoles A-C from aerial parts of Strobilanthes cusia in the traditional Chinese medicine Qing Dai have anti-IL-17 properties. Phytochemistry 2019, 162, 39-46. [CrossRef]

65. Leclerc, S.; Garnier, M.; Hoessel, R.; Marko, D.; Bibb, J.A.; Snyder, G.L.; Greengard, P.; Biernat, J.; Wu, Y.-Z.; Mandelkow, E.-M.; et al. Indirubins inhibit glycogen synthase kinase- $3 \beta$ and CDK5/P25, two protein kinases involved in abnormal tau phosphorylation in Alzheimer's disease: A property common to most cyclin-dependent kinase inhibitors? J. Biol. Chem. 2001, 276, 251-260. [CrossRef]

66. Eisenbrand, G.; Hippe, F.; Jakobs, S.; Muehlbeyer, S. Molecular mechanisms of indirubin and its derivatives: Novel anticancer molecules with their origin in traditional Chinese phytomedicine. J. Cancer Res. Clin. Oncol. 2004, 130, 627-635. [CrossRef] [PubMed]

67. Kunikata, T.; Tatefuji, T.; Aga, H.; Iwaki, K.; Ikeda, M.; Kurimoto, M. Indirubin inhibits inflammatory reactions in delayed-type hypersensitivity. Eur. J. Pharm. 2000, 410, 93-100. [CrossRef]

68. Kim, M.; Park, W.-T.; Park, S.A.; Park, C.W.; Ryu, S.U.; Lee, D.H.; Noh, Y.-Y.; Park, T. Controlling ambipolar charge transport in isoindigo-based conjugated polymers by altering fluorine substitution position for high-performance organic field-effect transistors. Adv. Funct. Mater. 2019, 29, 1805994. [CrossRef]

69. Weiner, M.P.; Costa, G.L.; Schoettlin, W.; Cline, J.; Mathur, E.; Bauer, J.C. Site-directed mutagenesis of double-stranded DNA by the polymerase chain reaction. Gene 1994, 151, 119-123. [CrossRef]

70. Matsui, T.; Udagawa, H.; Kishishita, S.; Skovlund, D.; Jin, Q. Recombinase-Mediated Integration of a Polynucleotide Library. Patent WO 2016026938A1, 20 August 2015. 